\title{
Divergences between the East and the West in the Construction and Management of the Written Space: General Principles and Specific Solutions
}

It is the margin that makes the page Jean-Luc Godard

The graphic design of books-both ancient and modern-generally represents the result of an intertwining of utilitarian, ideological and aesthetic factors that shape and steer the reception of a volume's content. Such is the frequency with which this proposition is cited and discussed-in the fields of codicology, bibliography, semiotics and sociology-that it requires no further affirmation. ${ }^{1}$

Technically speaking, the final layout of a page is accomplished through the 'construction' and 'management' of the written area, allied operations that contribute to the realisation of a project which is initially defined by its overall framework-in other words, the organisation of space destined to receive script. This is achieved through the following steps: the volume's ultimate dimensions are decided on; a grid is created on pages that determines the internal balance between 'full' and 'empty' spaces; the positioning of the text is settled on; and finally, the

Translated from the Italian into English by Mark Livesey. Original published as Maniaci, Marilena (2012), 'Costruzione e gestione dello spazio scritto fra Oriente e Occidente: principi generali e soluzioni specifiche', in Scrivere e leggere nell'alto medioevo, Spoleto, Fondazione Centro italiano di studi sull'alto medioevo (Settimana di studio, LIX), 473-514.

1 The bibliography for the mise en page and mise en texte of the medieval and modern book (the words impaginazione [in Italian] and layout [in English] both have rather narrower meanings) is, needless to say, vast, and therefore not readily summarised (even in a highly selective way) in a single footnote. However, if we confine ourselves to the manuscript, an initial list of suggested reading should include the references collected in Maniaci $2002\left(2005^{2}\right), 228-233$, and Agati 2009,240 , to be supplemented-especially with respect to the relationship between the appearance of text and ways of reading it-with titles suggested by Frank 1993, 79-81. For a richly illustrated volume of examples, see Martin / Vezin 1990. Research of a quantitative nature (the written page represents the 'home ground' of this kind of approach) will be amply exemplified during the course of the present contribution. A useful synthesis of prerequisites, results and future prospects is offered in Ornato 1997, 648-660 (La page écrite; construction, présentation, exploitation), and 660-677 (Autour de l'écriture). 
spacing-more or less commodious-of ruling is established. This phase is followed by the insertion into the predefined space of sufficiently well-organised and visually structured content. In turn, both phases can be broken down into sequences of tasks which are only occasionally documented in specific written sources, and whose after-the-fact reconstruction therefore has mainly to be entrusted to a direct consultation of surviving volumes.

From time to time, medieval artisans and copyists were charged with the task of making decisions aimed at fulfilling objectives which were-at least in part-contradictory: on the one hand it was necessary to guarantee the legibility of a text and the durability of the volume entrusted with its transmission to future generations, whilst on the other there was also the need to satisfactorily express the iconic implications of the book, in line with its ideological, sacred or purely functional orientation. When viewed in this way, the page can seem like a permanent 'field of tensions', but it can also be seen as an ideal 'laboratory' in which to carry out analyses, both synchronic and diachronic, of the connections and contradictions that influence transmission processes and the reading of texts.

If the making of a manuscript-and of the codex in particular-obeys, in the Mediterranean setting, a 'universal grammar' that codifies in a generally uniform way some of its fundamental characteristics, the various other book cultures have arrived at their own interpretations of the craft's basic rules, giving rise to more or less conspicuously discordant outcomes. The differences-which affect, though not exclusively, the appearance of the page-are not the result of sporadic individual choices dictated by taste, but instead represent an indirect reflection of historical, geographical, economic, social, cultural and even psychological factors. Herein, then, lies the interest of a comparative approach to the study of manuscript books-an approach which today is more often theorised about than actually applied in practice, although in the specific area of the mise en page, Eric Turner's investigation of the earliest history of Greek, Latin and Coptic ${ }^{2}$ codex manufacture represents a happy, but unfortunately isolated, exception.

As might be expected, any observations arising from a comparative study of different manuscript cultures can be placed alongside those made when an internal point of view is adopted within each distinct setting. Indeed, within the individual manuscript traditions the overall appearance and form of volumes underwent gradual transformations that more or less radically modified their appearance, their capacity, and their usability. Such transformations reflected changes in users and the designated function of volumes. In addition, significant differences point to synchronic local variations within each distinct manuscript culture.

2 Turner 1977. 
In an artisanal production context that lacked the strict application of uniformly defined and reproducible standards, a study of the chrono-geographical evolution of the mise en page not only calls for an archaeological examination of individual copies or an assessment of the overall appearance of specific types of volume, ${ }^{3}$ but also requires-in order to draw attention to and analyse general trends-a simultaneous analysis of a large complex of testimonial evidence. When the problem is viewed from this perspective, the application of statistical techniques becomes inevitable.

However, despite being well established and enjoying widespread application, statistical analysis is a methodological approach that continues to divide the opinion of scholars. Nevertheless, it is an approach which, in the analysis of the dimensional aspects of books and the written page, finds some of its more persuasive and fruitful applications. Only an evaluation centred on general trends allows one to identify, within the continuum of numerical data, the appearance of phenomena which are neither sporadic nor the product of pure chance-on condition, that is, that the limits set by the adopted approach, the nature of surviving documentation, and the quantity and quality of the data upon which the analysis is carried out (taking care to avoid making undue generalisations and drawing dubious conclusions) are accepted. Such an approach is far from being, in any sense, an ill-founded attempt at achieving 'objectiveness'.

Above and beyond the practical issues faced by the individual researcher working to build a well-populated database, the organisation and general parameters of a 'serial' investigation of the mise en page are inescapably affected by a variety of factors, chief among which is the difficulty of gathering and surveying in a systematic way the data necessary for conducting a close study of the page. Given the practical impossibility of directly examining many hundreds of manuscripts, one has to accept the necessity of substituting the task with a census of data collected from previously published descriptions. It has been noted, however, that even the most recent and carefully prepared catalogues neglect, or at least only partially survey, size parameters, and almost always fail to provide specific details on the distribution of margins. Not infrequently, the dimensions of

3 Even if it is impossible to provide a complete list of individual contributors, it seems indespensable to at least mention, for their exemplary value, the works of Jean Irigoin on Greek poetical manuscripts: Irigoin 1984; Irigoin 1985. A substantial bibliography concerning the mise en page of both Latin and Greek glossed manuscripts (see the selection of works cited in footnote 1) has accumulated over the last few years, whilst for codices written in vernacular, certainly worthy of mention is Careri et al. (eds) 2001. 
the written area, or even the overall arrangement of the text are also overlooked. ${ }^{4}$ In addition, the reliability of information inferred from already existing descriptions is subject to uncertainties of various kinds (e.g. doubts in relation to the degree of trimming, the measuring criteria employed, and frequent variations that occur in the mise en page within a single codex), all of which make it necessary to limit the analysis to a more macroscopic level..$^{5}$ Problems of a different (but no less awkward) nature affect reliability and accuracy when establishing dates and geographic origins, especially when these are drawn from old and/or heterogeneous descriptions. Then there is the difficulty of grouping together the content (often varied) of codices into appropriate categories, ${ }^{6}$ and the challenge presented by the scarcity of suitable indicators for the definition of subsets useful for performing analyses (according to graphic or textual typologies, qualitative hierarchies, destination contexts, reader categories, etc.). Finally, an unavoidable limitation lies in the highly heterogeneous chronological distribution of surviving evidence, which affects the late antique period more conspicuously than it does the Early Middle Ages (and the latter era is more noticeably affected in comparison to later centuries), a disparity which is only partially compensated for by the predilection of scholars for the earliest epochs, which are better known and documented.

The obstacles described above have not hampered, over the last few decades, the realisation of a number of wide-ranging research projects dedicated primarily

4 As regards photographic reproductions, where these are present they are often affected by cropping-sometimes drastic-of the blank areas that surround the text, the significance of which is unjustly ignored.

5 The external dimensions, which are normally mentioned even in the baldest of descriptions, are also altered to an extent that is difficult to quantify, although a tendency, either intentional or spontaneous, to round figures up due to insufficient or excessive measurements, is apparent. Appraisal of the effect of trimming (not on individual volumes, but instead on collections of surviving manuscripts) is a recurrent theme in codicological literature and has yielded different results: these range from the 'a few millimetres' postulated (on the basis of statistical observations) by Bozzolo / Ornato $1980\left(1983^{2}\right), 243-251: 244$, to almost 2-5 cm (to be precise, $4 \mathrm{~cm}$ for the upper margin, 4-5 cm for the lower margin, and $2 \mathrm{~cm}$ for the external margin) hypothesised by Tristano 1991,76 , in support of a questionable theoretical reconstruction of the procedure that a craftsman would have followed when squaring up sheets.

6 To the particular uncertainties presented by each category, one should add the 'multi-textual' character of many medieval codices: such volumes represent complex 'containers' of texts which are sometimes assignable to specific categories that differ greatly among themselves. The available descriptions of these types of books are often summary or partial, and do not distinguish their compositional unity. On the problems inherent to the so-called 'miscellaneous' codex, the reader should find it sufficient to refer to Crisci / Pecere (eds) 2004, and to Andrist / Canart / Maniaci 2013 (with an extensive discussion of the antecedent bibliography). 
to the mise en page of the Latin codex, and more recently to the Greek. As a result of such research, significant divergences in the volumes' general characteristics have emerged-despite the fundamental similarity of manufacturing methods-which are not limited, needless to say, to the mise en page, but also affect the 'underlying structures' of the two book traditions. Such differences appear independently from geographical and temporal subdivisions, content typologies and qualitative characteristics. Based on an examination (or re-examination) of corpora of old and new materials, I will seek to systemise and examine in detail (through a comparative study) the differences between the East and the West. I shall also build on-in an unavoidably schematic way-some of the cues provided by previous studies focused on the layout of Greek and Latin pages, and I shall enhance these with some additional facts suggested by a synchronic and diachronic examination of the two traditions.

The need to identify an area of investigation that corresponds to the theme being explored at Spoleto's Settimana has led me to apply the following limitations to my research:

a) As regards chronological reach: the period placed under examination stretches from the height of the $4^{\text {th }}$ century-the first parchment codices of dimensions and number of leaves that are reasonably close to the original ones date from this period-up until the end of the $7^{\text {th }}$ century, during which manuscript volumes independently underwent, both in the East and in the West, considerable changes that had a marked effect on their structure and appearance. At a meeting whose focus is the Early Middle Ages, an extension of the retrospective reach to the late antique period can be justified by the desire to draw attention to the circumstances in which-beginning in the late $6^{\text {th }}$ century-the Greek and Latin traditions diverge and become increasing distant from their shared late antique foundations. ${ }^{7}$ As for the 'low' limit, this has a purely conventional value, even if it is supported by a technical datum, namely the progressive assertion of paper over parchment codices in both cultural contexts, a phenomenon that had considerable consequences for the composition of quires and for the criteria applied to the utilisation of pages. ${ }^{8}$

7 Starting in the $7^{\text {th }}$ century, the bilingual nature of late-antique culture-the product of shared bureaucratic and cultural interests-was affected by a divergence of the relationships (causing them to be channelled in different directions) between Latin and Greek writings, books and documents. See also the survey by Cherubini / Pratesi 2010, 159 onwards, with an extensive bibliography.

8 Even if the first affirmations of the use of paper date back to the $11^{\text {th }}$ century in the Spanish domain, and to the beginning of the $9^{\text {th }}$ century in the Greek domain (albeit sporadically), its presence increases significantly in both areas only during the $13^{\text {th }}$ century (Agati 2009, 86-87). The dearth of specific investigations into the speed at which the new support became established-and also into its greater perishability-makes it difficult, as far as the earliest phases are 
b) As regards writing materials and book typologies, I shall focus my attention on the parchment codex. I will exclude from the discussion both the bookroll (which, despite not entirely disappearing from use, plays an altogether marginal role in the Middle Ages) and the papyrus codex, which was employed for only a limited time from late antiquity to the dawn of the Middle Ages. ${ }^{9}$ For equivalent and specular reasons, I shall avoid any mention of the paper codex, which was even less frequently employed during the period in question.

c) Finally, concerning the objectives of my analysis, on account of time constraints and the incomplete nature of the documentation I have been able to gather, it will not be possible to examine all the implications raised by the study of the mise en page. Therefore, upstream in the codex manufacturing process the more technical aspects of page construction will be excluded (i.e. pricking and ruling, particularly in relation to the numerous types observed), whilst downstream, aspects inherent to the 'typography of the written page' ${ }^{10}$ will not be taken into consideration, such as its segmentation into lines and the division of words, the use of 'editorial devices' aimed at enhancing the legibility of text (e.g. titles, initials, filling elements, running titles, incipit and explicit highlighted in various ways), ${ }^{11}$ and the selection and use of abbreviations. Thus, the subject of the investigation will be a circumscribed (but nonetheless relevant) 'package' of purely spatial parameters: above all, total dimensions, the distribution of the text, the number of lines and, wherever possible, ${ }^{12}$ the dimensions of the written area and of the four margins-parameters which are indispensable in order to be able to investigate the governing principles lying behind the mise en page, of which only occasional traces remain in the few surviving layout 'recipes'. ${ }^{13}$

concerned, to arrive at a more accurate evaluation of the speed at which the material was adopted (information about which therefore has to be entrusted to occasional accounts in written sources, and a few sporadic quotes in individual manuscripts).

9 Findings that remain of fundamental significance in relation to the external dimensions of the papyrus codex can be found in Turner 1977, 13-25. More recent, and persuasive, is the in-depth study by Crisci 2003, which critically re-examines and re-evaluates the presence of papyrus in Eastern book production up until the beginning of the $8^{\text {th }}$ century. As regards bookrolls, which lie outside the bounds of this contribution, I will confine myself to mentioning Johnson 2004.

10 The expression was coined by Gumbert 1992.

11 Despite being somewhat concise in nature, the general observations on the expedients used to structure text and enhance the legibility of medieval books are made admirably clear in Gumbert 1989. 12 'Même des caractéristiques aussi élémentaires que les dimensions reflètent de près [...] les mutations intervenues au cours des siècles dans l'aspect matériel du livre' (Bozzolo / Ornato, 1980, 252).

13 For the said 'recipes', see the text corresponding to footnotes 70-75 below. As regards details of the problems they raised, manuscripts presenting with unusual mise en pages were not taken 
For reasons already stated above, the corpora that provide the investigation's 'backbone' are, unavoidably, disparate in nature, being partly derived from a direct examination of several hundred manuscripts (mostly Greek), and partly from a perusal of manuscript catalogues and the findings obtained during previous research projects which have been made freely available by their authors. ${ }^{14}$ In order to document-albeit in a partial and rather disjointed way-the entire historical time span examined, the following materials were utilised:

\section{(a) For the Latin context}

1) For the centuries leading up to the $8^{\text {th }}$ (but also including some material dating from subsequent decades), ${ }^{15}$, a thorough first-hand examination of the original Codices Latini Antiquiores ${ }^{16}$ series, albeit limited to manuscripts whose dimensions are equivalent to, or at least significantly close to, those of the originals, and therefore excluding not only rolls, fragments and palimpsests, but also codices expressly marked as having been heavily trimmed. ${ }^{17}$ A total of 1,015 suitable

\footnotetext{
into account (e.g. those with textual content supplemented with comments, regardless of their arrangement).

14 Limitations in relation to the qualitative and quantitative heterogeneousness of the information used will be provided from time to time during the presentation of individual results emerging from the investigation. In any event, for all the values presented in tables and discussed in the text, the basis of the calculation, which will vary according to the available data, will be shown in brackets, thereby enabling the reader to identify values that cannot be regarded as reliable due to statistically insignificant numbers.

15 It is common knowledge that the selection criteria applied by Lowe, partly of his own volition, permit the inclusion of manuscripts in the group that without doubt date from after the end of the $8^{\text {th }}$ century (with deviations which can, in some cases, extend to several decades).

16 I have not included in the census the supplementary material collected in Bischoff / Brown 1985 and Bischoff / Brown / John 1992.

17 In the case of palimpsest manuscripts, which were frequently used in the manufacture of codices of mediocre quality, the dimensions and mise en page of the original codices run the risk of being skewed by those of the overwritten ones. On the other hand, it should be pointed out that the surveying approach adopted by Lowe suffers from inaccuracies that are rather difficult to quantify: e.g. the rounding of figures, approximations prefixed with the word 'circa', and uncertainties as regards the treatment of the narrow columns positioned alongside the written area (on this last issue, see Muzerelle 1989, 131). The distortions result from the random distribution within the sample, and as such do not appear to cast doubt on the validity of the overall trends that emerged during the analysis.
} 
volumes were examined, representing a little over half of the $1,865^{18}$ surveyed by Elias Avery Lowe in his monumental work, generally considered 'the supporting column of any research on book production in late antiquity'. ${ }^{19}$

2) For the $9^{\text {th }}$ to $12^{\text {th }}$ centuries, a rather 'mixed bag' composed of a little more than 1,650 items, produced variously in the north and south of Europe. This group represents the fruit of various surveys and perusals. ${ }^{20}$

\section{(b) For the Greek context}

1) For the centuries leading up to the $9^{\text {th }}$, a small corpus, including a survey of Greek majuscule codices (carried out by Pasquale Orsini). Unfortunately, in the case of the Greek codices antiquiores, the difficulty in establishing essential measurements created an obstacle that could only be partially worked around, hence markedly limiting the number of volumes whose total dimensions could be determined (245), and limiting to an even greater extent the number of volumes for which it was possible to ascertain-either directly or indirectly-the size of the written area and width of the margins (48 and 27, respectively). Furthermore, a sample composed in this way cannot be truly representative, given that, in addition

18 According to the calculations of John 1990, 96. Despite the various topics implied by the title, John's article only presents the results of a few basic observations, which largely speaking regard-above and beyond the chrono-geographical distribution of the codices catalogued by Lowe-pricking positioning and method of execution and ruling (systems and types, albeit limited to the distribution of columns). The only information on the mise en page regards the positioning of text in one or more columns and the diffusion of a square, or somewhat square, written area.

19 Cavallo 1984, 417.

20 One is in fact dealing with a randomly selected sample (composed of exactly 1,665 codices) which, over time, has had data from various other surveys added to it. The majority of such data is ascribable to the following researchers and authors: Carla Bozzolo and Ezio Ornato (Bozzolo / Ornato 1980); Birger Munk Olsen (Munk Olsen 1982-1989); Peter Gumbert (Gumbert 1984); the team responsible for research on the material structure of $11^{\text {th }}$-century Italian manuscripts (Bianchi et al. 1993); and the authors of various catalogues of dated codices, used for an experiment in electronic conversion (about which see Maniaci / Ornato 2002). The codices examined are chronologically distributed as follows: $9^{\text {th }}$ century $=163$ items; $10^{\text {th }}$ century $=126$ items; $11^{\text {th }}$ century $=630$ items; $12^{\text {th }}$ century $=733$ items. The entire Latin sample (including the volumes extracted from the $C L A$ ) is composed of 2,680 items, arranged (approximately) into centuries as follows: $4^{\text {th }}$ century $=10$ items; $5^{\text {th }}$ century $=46$ items; $6^{\text {th }}$ century $=90$ items; $7^{\text {th }}$ century $=85$ items; $8^{\text {th }}$ century $=794$ items; $9^{\text {th }}$ century $=166$ items; $10^{\text {th }}$ century $=126$ items; $11^{\text {th }}$ century $=630$ items; $12^{\text {th }}$ century $=733$ items. 
to uncertainties as regards the dating of volumes, it is also affected by typological distortions (for example, a superabundance of codices written in biblical majuscule $)^{21}$ that can only be partially rectified by using two 'control groups', which in turn are unbalanced in their own way. The two 'control groups' were sourced, respectively, from a list published in the appendix of Eric Turner's monograph, ${ }^{22}$ and from the bibliography of New Testament codices compiled by Kurt Aland. ${ }^{23}$ Observations on the mise en page of Greek codices in majuscule script will therefore be limited to a small amount of data that can be considered reliable (until more detailed information becomes available in the future).

2) For the period stretching from the $9^{\text {th }}$ to the $12^{\text {th }}$ century, a total of 681 Byzantine parchment manuscripts, all of which have been examined in person by the present author during other research projects. ${ }^{24}$

The sundry composition of the samples and heterogeneity of the available data within the various subdivisions called for a circumspective evaluation of the results, which was therefore limited to analysing a few general characteristics which emerged with greater clarity. In particular, it did not seem prudent to explore in a systematic way-apart from making a few occasional remarks-the relationship between the mise en page and the content of volumes, which would have required data acquisition and analysis of a more precise and detailed kind. The same applies to the relationship between page layout and the different graphic typologies used in the East and in the West. For the same reason, it would have been imprudent to stretch beyond a certain point the interpretation of a few divergent trends which can be distinguished among the various regions of Medieval Europe. As will become clear in due course, despite the considerable

21 Described in Orsini 2005; I thank Pasquale Orsini for having generously allowed me to make use of the material gathered by him.

22 Turner 1977, dealing with a total of 130 parchment volumes of known or at least reconstructible dimensions, previously examined in Maniaci 2002.

23 Aland 1994 (or. 1963). The list can now (albeit not very easily) be consulted online at http://intf.uni-muenster.de/vmr/NTVMR/ ListeHandschriften.php (last access 07/09/2021).

24 In particular, Maniaci 2002, in which the characteristics and method employed for assembling the sample are explained (49-54). Due to a dearth of recorded measurements (data is limited to the height and width of pages), the database, resulting from a perusal of Sautel's list of 4,000 codicological items) proved to be unsuitable for the purposes of the present investigation (Sautel 1995, about which see Maniaci 2002, 25-49). The Greek codices examined (a total of 964) are chronologically distributed as follows: $4^{\text {th }}$ century $=3$ items; $5^{\text {th }}$ century $=8$ items; $6^{\text {th }}$ century $=16$ items; $7^{\text {th }}$ century $=$ items $; 8^{\text {th }}$ century $=18$ items; $9^{\text {th }}$ century $=111$ items; $10^{\text {th }}$ century $=316$ items; $11^{\text {th }}$ century $=305$ items; $12^{\text {th }}$ century $=$ 176 items. 
chronological and geographical breadth that the investigation covers, a number of basic trends emerge in a meaningful and coherent way, irrespective of contexts, content and manuscript typologies.

\section{Overall dimensions (size)}

An examination of overall dimensions made it possible to draw some initial comparisons.

Between late antiquity and the end of the $12^{\text {th }}$ century, the average dimensions of Latin codices remained very stable. ${ }^{25}$ The $11^{\text {th }}$ century was an exception, though, since this was a period in which the examined sample shows a significant increase in dimensions, accompanied by much greater dimensional variety, followed, once again, by a reduction in size. ${ }^{26}$ It is noticeable that the average 'size' (i.e. the sum of the height and width of a volume) lies, in both the East and the West, exactly on the boundary that divides the two classes of volumes (smallmedium, and medium-large, ${ }^{27}$ as defined by Carla Bozzolo and Ezio Ornato, based on the nomenclature used in medieval Latin inventories) ${ }^{28}$

25 The unification of the $4^{\text {th }}-7^{\text {th }}$ centuries in the tables is aimed simply at making it easier to draw a direct comparison between Greek and Latin codices, taking into account the low number of examples of the latter contained in the sample. Given that, for the Western book, the transition from the $6^{\text {th }}$ to the $7^{\text {th }}$ century brought with it considerable and significant changes in production contexts and methods (including the spread of lay artisans and their taking the place of craftsmen in ecclesiastical scriptoria), where it seems appropriate-and, indeed, possible-figures in relation to each of the four earliest centuries will be addressed separately in a note. As regards sizes, means do not vary greatly, and therefore do not merit consideration. The materials, graphical appearance and content of $5^{\text {th }}$-century Latin volumes are addressed in a recent contribution by Giovè Marchioli 2010.

26 The variance (an index of dispersion obtained by calculating the average of the squared differences of data values from their mean) almost doubles, increasing from 11,299.84 (the cumulative value for the $8^{\text {th }}-10^{\text {th }}$ centuries) to $20,858.34$ for the $11^{\text {th }}$ century (and to $18,188.15$ for the $12^{\text {th }}$ century). 27 This is the most common indicator employed in codicological literature, although not without some reservations: see Gumbert 2001, and Muzerelle 2007.

28 Bozzolo / Ornato 1980, 218: small volumes < $320 \mathrm{~mm}$; small to medium volumes 321-490 mm; medium to large volumes $491-670 \mathrm{~mm}$; large volumes $>670 \mathrm{~mm}$. As a curiosity, it should be noted that the sizes documented in the Latin sample range from a minimum of $128 \mathrm{~mm}$ to a maximum of $1,015 \mathrm{~mm}$. 


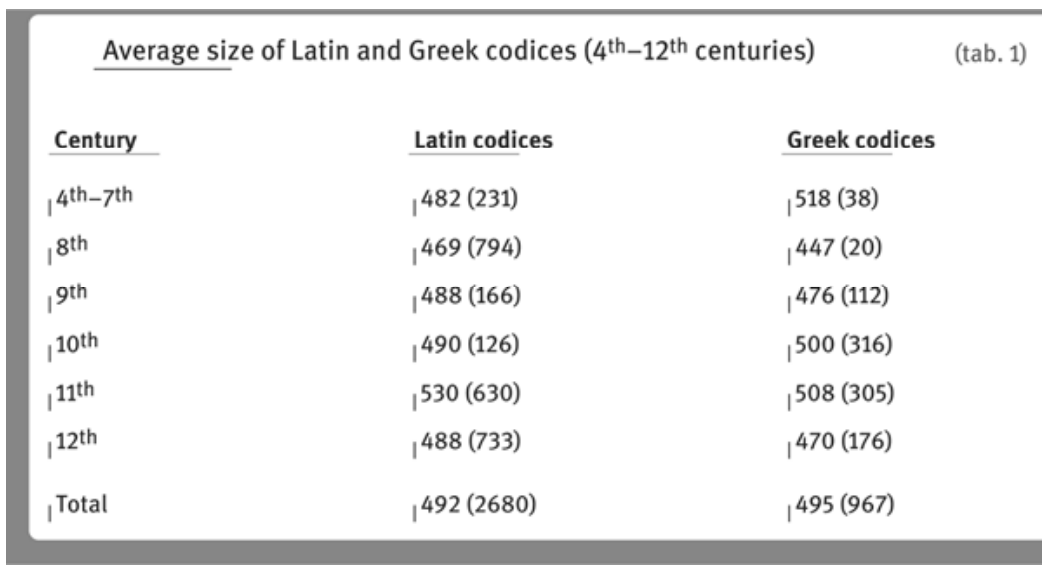

Tab. 1: Average size of Latin and Greek codices $\left(4^{\text {th }}-12^{\text {th }}\right.$ centuries)

It should be noted that the calculations made by Bozzolo and Ornato for Northern France-relating to a sample of 6,200 volumes of biblical, patristic, theological and hagiographic content-differ slightly in the $9^{\text {th }}, 10^{\text {th }}$ and $11^{\text {th }}$ centuries (respectively $500 \mathrm{~mm}$ for the $9^{\text {th }}-10^{\text {th }}$, and $524 \mathrm{~mm}$ for the $11^{\text {th }}$ ), and a little more in the $12^{\text {th }}$, which does not see a reduction $(527 \mathrm{~mm}) .{ }^{29}$ Therefore, the size reduction seems mostly to affect the southern regions of Europe (where measurements descend from 563 to $468 \mathrm{~mm}$ ).

The average dimensions of Greek codices largely follow a similar trend, ${ }^{30}$ since these, too, between the $11^{\text {th }}$ and $12^{\text {th }}$ centuries, and for all types of content, undergo a considerable reduction in size, even when one takes into account the period of crisis that preceded the fall of Constantinople into the hands of the Crusaders. ${ }^{31}$ As regards the exceptionally high value recorded for volumes dating to the earliest centuries, this is very likely attributable to a distortion caused by a

29 Bozzolo / Ornato 1980, 265.

30 The codices examined ranged from 164 to $764 \mathrm{~mm}$ in size.

31 For a more detailed analysis of this issue, see Maniaci 2002, 114-121. The values in the table are fully confirmed by the means calculated for the largest samples (ibid., 111). The chronological evolution observed between the $9^{\text {th }}$ and $12^{\text {th }}$ centuries includes (albeit in varying degrees) the entire range of textual typologies (ibid., 114), although it is marked by a quantitative reduction in codices of larger dimensions (homilaries and patristic collections), which hints at a general decline in the quality of book production, a scenario which is further reinforced by an overall impoverishment of qualitative parameters, as the absence of gilding and defects in parchment etc. (ibid., 114-121). 
superabundance in the sample of premium quality volumes of biblical content. ${ }^{32}$ Conversely, the mean recorded for 131 codices gleaned from Eric Turner's lists is a lot lower, at just $340 \mathrm{~mm},{ }^{33}$ which is also decidedly inferior to the value recorded for coeval Latin volumes. The mean for the $4^{\text {th }}$ to $7^{\text {th }}$-century gospels and lectionaries drawn from Kurt Aland's inventory registered at $380 \mathrm{~mm}$. Unfortunately, the available data are not sufficient to make it possible to investigate the root cause of such differences-indeed, a study of the overall dimensions of Greek codices in majuscule script would certainly call for an in-depth investigation based on a far wider-reaching and more precisely targeted survey.

Needless to say, by only considering average values, a very approximate and rather 'flat' version of a complex picture emerges, but one which in any event makes it possible to cast doubt on the legitimacy of the rather drastic and oversimplified comparison of the ancient codex's essential elegance and ease of handling with the rather 'rigid' monumentality of volumes of the Early Middle Ages, which were considered objects of veneration rather than books to be read and employed as study aids. ${ }^{34}$ An analysis of the way in which the recorded sizes are distributed throughout the various historical periods makes it possible to clarify matters, since it exposes-lying behind the seemingly uniform average values-some differences that merit our attention (Chart 1).

Up until the $8^{\text {th }}$ century, the distribution of sizes with respect to the Latin codices is characterised by a clear convergence towards a common peak, roughly corresponding in size to a sheet of today's A4 paper ( $210 \mathrm{~mm} \times 297 \mathrm{~mm})$, although one occasionally encounters volumes that measure more than $700 \mathrm{~mm}$ in size. ${ }^{35}$ Truly large Latin codices-which is say those of monumental proportions measuring up to $1,000 \mathrm{~mm}$-start to appear more frequently in the $9^{\text {th }}$ century, and occur above all in the $11^{\text {th }} .36$

32 Two of the three $4^{\text {th }}$-century codices examined are the famous Vatican $(540 \mathrm{~mm})$ and Sinaitic $(720 \mathrm{~mm})$ Bibles. $80 \%$ of the volumes dating from the three successive centuries are in biblical majuscule ( 28 of 35$)$.

33 The mean is affected by the significant presence of volumes of considerably reduced size; see Maniaci 2002, 82, Table 2.

34 See, for example, the rather peremptory judgement formulated in the opening of the wellknown essay by Petrucci 1972.

35 For the $4^{\text {th }}$ to $8^{\text {th }}$ centuries, above the $700 \mathrm{~mm}$ threshold one finds only 16 volumes out of a total of 1,025 , which equates to about $1.05 \%$, and only 8 of them exceed a value of $800 \mathrm{~mm}$.

36 For the $10^{\text {th }}$ and $11^{\text {th }}$ centuries a total of 80 manuscripts measuring more than $700 \mathrm{~mm}$ in size was counted among the 756 included in the census, representing about $11 \%$; half of these exceeded $800 \mathrm{~mm}$, and 11 of them measured from 900 to more than 1,000 mm. 


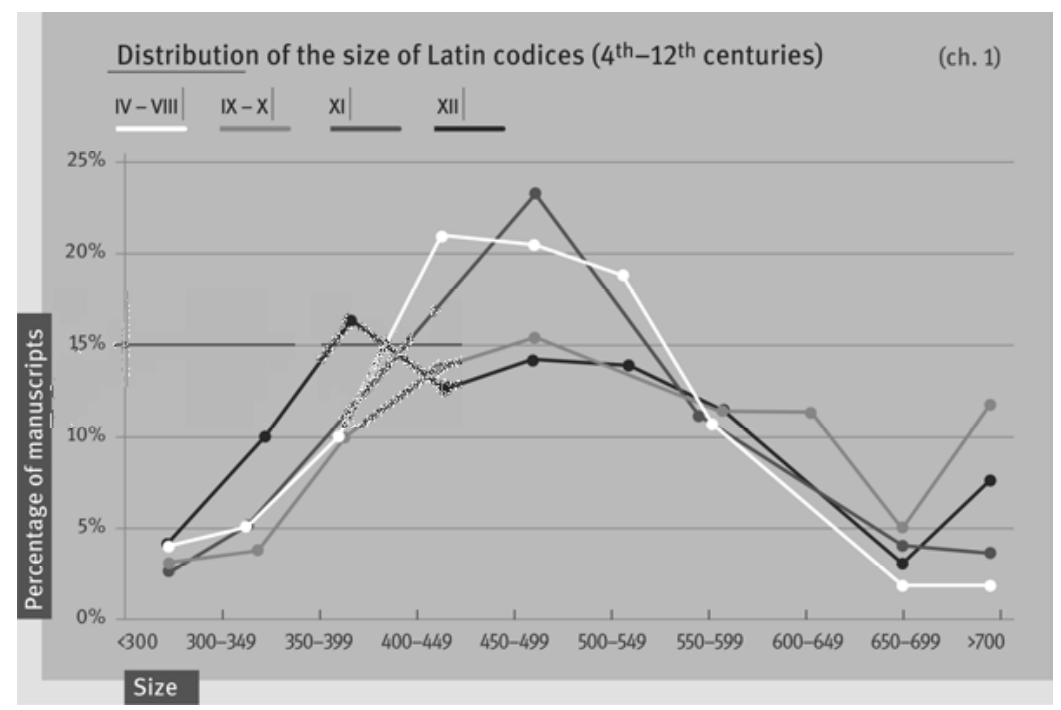

Chart 1: Distribution of the size of Latin codices $\left(4^{\text {th }}-12^{\text {th }}\right.$ centuries)

In the $11^{\text {th }}$ and $12^{\text {th }}$ centuries, the range of sizes seen in the Latin context exhibits, overall, a much greater degree of variation, with about $80 \%$ of volumes ranging from $380 \mathrm{~mm}$ to $665 \mathrm{~mm}$ in the $11^{\text {th }}$ century, and from $350 \mathrm{~mm}$ to $580 \mathrm{~mm}$ in the $12^{\text {th }}$, thus the two distribution patterns (from this viewpoint) are virtually identical, albeit somewhat 'out of phase'. It is interesting to note that the curves representing the $11^{\text {th }}$ and $12^{\text {th }}$ centuries differ from those presented by Carla Bozzolo and Ezio Ornato for the French codices, which are distinguished (above all in the $12^{\text {th }}$ century) by a clustering around two peaks. These peaks were associated by the two scholars with skins of similar or identical sizes being folded in two different ways, respectively in-4 (the outcome of two successive folds) and in-8 (the outcome of three successive folds), resulting in larger manuscripts (of more or less similar size) and smaller manuscripts (again, of more or less similar size), respectively. ${ }^{37}$

37 Bozzolo / Ornato 1980 (1983²), 257 and Table I, and 338-339 (graphs E and F). The two peaks correspond to the following succession of sizes: $420-494 \mathrm{~mm}$ and $552-607 \mathrm{~mm}$ (11 ${ }^{\text {th }}$ century), and 395-444 mm and 545-594 mm (12 ${ }^{\text {th }}$ century). In the $12^{\text {th }}$ century, a much less pronounced third peak appears that corresponds to larger size values $(745-794 \mathrm{~mm})$. With respect to paper codices, where standardisation reaches a maximum, the peaks are much more conspicuous. 
The same tendency is also seen in the French component of the sample presently under examination, but not in codices originating from other regions (in the north and south of Europe), which reinforces doubts about the widespread use of a symmetrical fold in the creation of quires. Even if a variation in working habits could account for the application of different ways of subdividing skins, this possibility is yet to be confirmed through a direct analysis of the characteristics of parchment used in the manufacture of individual codices. ${ }^{38}$

With respect to the East (and also the West), affirmation of the minuscule script in book production was immediately accompanied by a significant widening of the codex's size range. This trend persisted throughout the centuries subsequent to the $9^{\text {th }}$, when a wholly episodic presence of large format volumes of Greek manufacture is seen. ${ }^{39}$ The only noteworthy development that occurs is a significant increase in small volumes in the $12^{\text {th }}$ century. This trend is symmetrical, as it were, with the higher frequency of large volumes that appeared in the $11^{\text {th }}$ century, and is correlated to an overall decline in quality, representing a clear reflection of this crisis-gripped period (Chart 2).

38 According to Gumbert 2000, 86, 'at least until the ninth century skins were normally not divided into bifolia by folding, but by cutting out sections of the desired size in any way they would fit'. An investigation carried out a few years ago on a small collection of Greek codices which was based on an examination of the axillae (see Maniaci 1999 [in this volume, 309-321]) confirms the opinion of the Dutch scholar, but analogous research on the Latin context is lacking. Some surveys carried out by the present author on individual pre- $12^{\text {th }}$-century codices have revealed a variable position of the axillae on leaves within one and the same volume and have made it possible to distinguish, for the Early Middle Ages, a situation in which a desire to exploit skins to the maximum (through a methodical folding of sheets in half) seems to take precedence over an optimisation of the working method. The perfunctory application of the folding method (without taking into account visible evidence on skins) represents the basis of a study by Nelson / Bona 1991. The two authors propose, albeit somewhat dubiously, the reconstruction of size relations within a small group of late Byzantine illuminated codices, with the aim of evaluating respective costs. Additionally, they hypothesise (somewhat optimistically) a possible computerised automation of the comparison procedure.

39 In the sample examined here, a total of 10 codices can be counted for the period stretching from the $9^{\text {th }}$ to the $12^{\text {th }}$ century, all of which measure well under $800 \mathrm{~mm}$ in size (the mean is $725 \mathrm{~mm}$ ). 


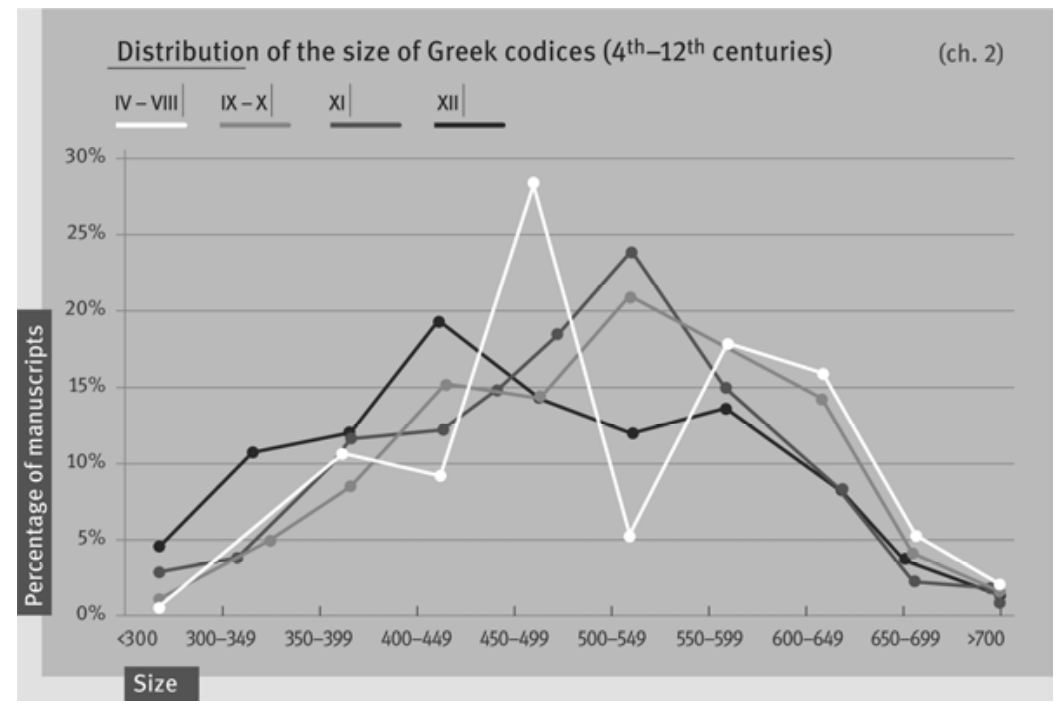

Chart 2: Distribution of the size of Greek codices $\left(4^{\text {th }}-12^{\text {th }}\right.$ centuries)

Concerning the average size of leaves and their development over time, taken as a whole, the Greek and Latin codices on parchment generally exhibit similar ${ }^{40}$ characteristics, with the exception of the largest volumes (i.e. those measuring more than $750 \mathrm{~mm}$ in size), which are entirely unknown-as has already been stated-in the Greek context.

Given that the systematic use of animals of significantly different sizes in Eastern and Western ${ }^{41}$ book production seems improbable, the absence of very large Greek codices could be explained by the use of particular techniques (on the part of artisans) for the subdivision of skins, aimed at achieving a better use of the potential surface area offered by a single skin (e.g. the division of larger

40 If, in the earliest centuries, the size distribution of Greek majuscule codices matches almost exactly that of Latin volumes in capital and uncial script, the deviation with respect to the sample of parchment volumes gleaned from Turner's lists, which-as has already been stated-are always distinctly smaller, seems to be clear (and at present without explanation).

41 It is true that in Northern Europe Western Latin production saw the use (though not exclusively) of larger calfskin parchments, but these-as has been noted-are very rare south of the Alps. Some of the largest $11^{\text {th }}$-century Latin volumes were certainly made using parchment derived from sheepskin (in particular, complete volumes known as 'Atlantic' Bibles, which can measure more than 1,000 $\mathrm{mm}$ in height: see Maniaci 2000 [in this volume 35-63]). 
skins using two perpendicular cuts in ' $\mathrm{T}$ ' form, so as to produce three bifolia of medium size instead of two larger ones, or alternatively four smaller ones). ${ }^{42}$

All things considered, in both production areas one observes a phenomenon of progressive size differentiation. Using a broader sample and a better targeted survey, a possible correlation between greater heterogeneousness of textual typologies and the manner of their use ought to be investigated.

In contrast to overall dimensions, which were subject to considerable variations (both synchronically and diachronically), 'proportion'-conventionally expressed as the relationship between width and height ${ }^{43}$-evolved over the course of time, but proves to be relatively stable throughout the various historical eras, independent of the script type or textual content of the codices.

The means calculated for the Latin corpus tally perfectly with those previously arrived at by Bozzolo and Ornato ${ }^{44}$ in their calculations (Tab. 2). The figures effectively confirm, for the rest of medieval Europe, what has already been noted for the north of France, namely a gradual and widespread shift, above the $45^{\text {th }}$ parallel, towards a so-called 'invariant' value (0.707), which is not affected by successive folds of a single sheet along its short axis, and as such was subsequently approved as a norm by medieval papermakers. (Not by chance, the same proportion is used for the most widely used format in today's paper industry. ${ }^{45}$ As in the case of dimensions, the overall tendency towards a levelling out of proportions, which is also borne witness to by the reduction in the variance, ${ }^{46}$ is accounted for by scholars as being the result of a desire to standardise the external appearance of large and small books made by effecting one or more successive symmetrical subdivisions of skins which had first been trimmed so as to reduce their natural breadth.

42 In relation to so-called in-sexto subdivision, see Maniaci 1999.

43 The use of the inverse relationship H/W-preferred (for example) by Irigoin 1990, 123, or more recently by Cherubini 2004, 247-249-apart from making less immediately apparent a page's 'slender' or 'squared off' appearance, does not facilitate comparisons.

44 The value provided by Bozzolo and Ornato relates to the $9^{\text {th }}$ to $10^{\text {th }}$ centuries.

45 The relevant format standard is ISO 216, which was previously codified at the beginning of the $20^{\text {th }}$ century by the Deutsche Institut für Normung (DIN). The $\mathrm{A} 3$ format is of almost exactly the same dimensions as the reçute format inscribed on the famous $13^{\text {th }}$-century 'Bologna stone'. The reçute format became firmly established in the world of European papermaking as the 'common sheet'.

46 See Bozzolo / Ornato 1980, 287. 


\begin{tabular}{|c|c|c|c|}
\hline \multicolumn{4}{|c|}{ Average proportion of Latin and Greek codices ( $4^{\text {th }}-12^{\text {th }}$ centuries) } \\
\hline Century & Latin codices & Bozzolo / Ornato & Greek codices \\
\hline $1^{4^{\text {th }}-7^{\text {th }}}$ & $0.767(231)$ & - & $0.791(38)$ \\
\hline $1^{8^{\text {th }}}$ & $0.701(794)$ & |0.696 & $0.710(18)$ \\
\hline $1^{9^{\text {th }}}$ & । $0.739(166)$ & । 0.740 & । $0.737(111)$ \\
\hline$\left.\right|^{1} 0^{\text {th }}$ & $0.734(126)$ & | 0.74044 & |0.748 (316) \\
\hline$\left.\right|^{11^{\text {th }}}$ & |0.695(630) & । 0.709 & $0.769(305)$ \\
\hline $1^{12^{\text {th }}}$ & । $0.685(733)$ & । 0.690 & $0.748(176)$ \\
\hline ।Total & । $0.705(2680)$ & । 0.715 & 0.754 (964) \\
\hline
\end{tabular}

Tab. 2: Average proportion of Latin and Greek codices $\left(4^{\text {th }}-12^{\text {th }}\right.$ centuries)

The progressive trend towards stable proportions, which was already evident in the $8^{\text {th }}$ century, was temporarily interrupted in the $9^{\text {th }}$ to $10^{\text {th }}$ centuries, during which, across the board, there was further growth in a preference for relatively wide volumes. In the north-west of France, this phenomenon was related to the 'revival' and transcription of late antique models: a revival that was well represented, according to Marco Palma's findings, by a type of 'antique-style' academic volume of a 'small, classic and 'square' appearance, whose text was laid out in two columns surrounded by spacious margins. ${ }^{47}$ However, this typology-of which Palma identified about fifteen witnesses of non-specific provenance-only held a minority position following the widespread appearance of small and predominantly narrow codices.

The 'revival' of wide proportions is plain to see in the whole of Northern Europe (i.e. Northern France, Germany and the Low Countries) and is not limited to volumes containing classical texts, but instead encompasses, albeit to varying degrees, almost all textual typologies (Tab. 3). As regards France, the 'Pythagorean' ratio (i.e. proportions equal to 4/5), or even squarer-looking standard forms (roughly 4/5 proportioning), were employed above all at Reims and Tours, but are much less evident in other scriptoria. ${ }^{48}$ In other areas of Europe, in the

47 Palma 1998.

48 See Bozzolo / Ornato 1980 (1983²), 297. A fragment of a $9^{\text {th }}$-century codex (Paris, Bibliothèque nationale de France, Par. lat. 11884, ff. 2-4), originating from (and probably produced in) the Abbey of Saint-Remi at Reims, has come down to us bearing the oldest known layout 'recipe' 
absence of adequate survey data, the reduced numbers constrain one to be cautious in the interpretation of means, which in the case of Southern Italy, at any rate, seem to differ from those established for the countries lying north of the Alps (Tab. 3). ${ }^{49}$

\begin{tabular}{|c|c|c|c|}
\hline \multicolumn{4}{|c|}{ Average proportion of Latin codices in Northern and Southern Europe (tab. 3) } \\
\hline Century & D, F, NL & $\underline{\mathrm{I}, \mathrm{E}}$ & Total \\
\hline $1^{4^{\text {th }}-7^{\text {th }}}$ & $0.766(41)$ & $0.767(142)$ & $0.767(183)$ \\
\hline $1^{8^{\text {th }}}$ & |0.688(516) & । $0.718(114)$ & $0.693(630)$ \\
\hline $1^{9^{\text {th }}}$ & | $0.744(91)$ & $0.690(9)$ & $0.739(100)$ \\
\hline $1^{10^{\text {th }}}$ & | $0.750(70)$ & । $0.712(9)$ & $0.746(79)$ \\
\hline$\left.\right|^{11^{\text {th }}}$ & ।0.716 (231) & । $0.684(297)$ & । $0.698(528)$ \\
\hline $1^{12^{\text {th }}}$ & $0.684(349)$ & । $0.677(127)$ & |0.684 (376) \\
\hline |Total & 0.702 (1298) & |0.710 (589) & 0.704 (1896) \\
\hline
\end{tabular}

Tab. 3: Average proportion of Latin codices in Northern and Southern Europe

jotted down (in a slightly later hand) in the lower margin of f. $2 \mathrm{v}$. The 'recipe' implies the adoption of 4/5 page proportioning (see the text corresponding to footnotes 70-75 below).

49 As a result of his study of a small group of volumes (a little over thirty), Tristano 1991, 81, claims she is able to infer, by observing a higher level of dispersion of the proportion, 'a certain sluggishness in Southern Italy to adapt to the models and techniques followed by the rest of Europe'. Given that explicit information on the number of Southern Italian codices 'of the $8^{\text {th }}$ century in uncial, and of the $9^{\text {th }}$ and $10^{\text {th }}$ centuries in minuscule' taken into consideration is not provided, and also that in the sample I have examined Southern Italy is not adequately represented for the centuries prior to the $11^{\text {th }}$, it is impossible for me to appraise the soundness of the scholar's hypothesis. However, I can state that the 574 codices of generic Italian origin examined by me exhibit, for the $8^{\text {th }}$ to $10^{\text {th }}$ centuries (118 volumes), an average proportion of 0.705 , which decreases to 0.683 in the $11^{\text {th }}$ century (293 volumes). I also note that the adherence to ancient practices-which did not change significantly between late antiquity and the Early Middle Ageson the part of Irish artisans is perhaps not entirely a product of chance (the phenomenon is plain to see in the $8^{\text {th }}$ century; the relative meagreness of the sample makes it impossible to chart any changes which occurred in successive centuries). More generally speaking, these and other differences suggested by the figures for the various areas of Europe should be subjected to a more precise analysis. 
The preference for a 'square' page layout is seen most clearly in late antique Greek codices, whose proportions remain unchanged at about $0.80(4 / 5)$ throughout the $6^{\text {th }}$ century, with even higher values seen in the most ancient volumes. However, a century-by-century calculation of means reveals a gradual shift, although not always without a margin of doubt-taking place between the $4^{\text {th }}$ and $8^{\text {th }}$ centuries-towards 'slimmer' standards, a trend also observed simultaneously in the Latin corpus ${ }^{50}$ (Tab. 4).

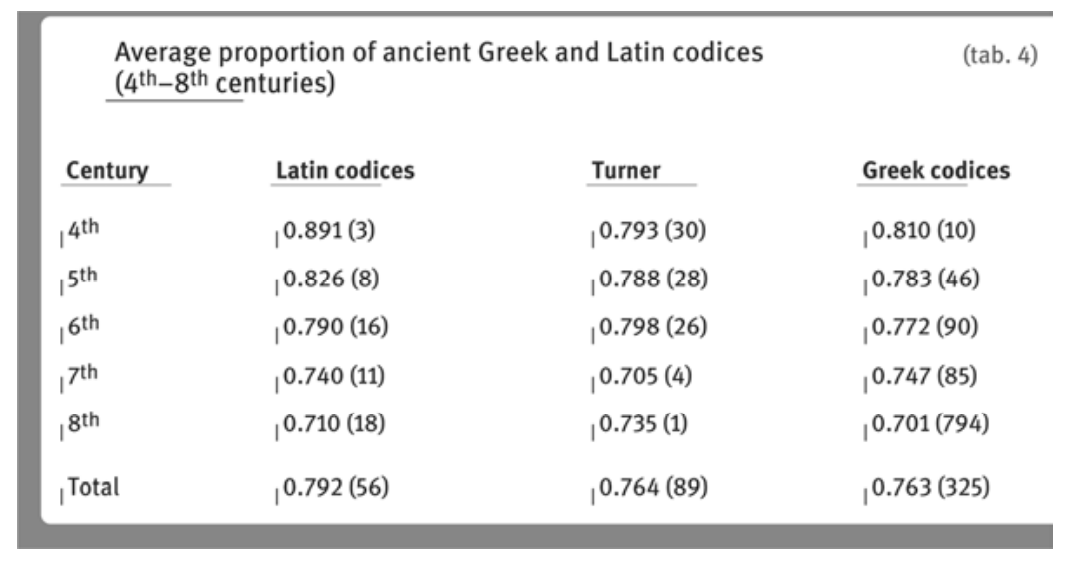

Tab. 4: Average proportion of ancient Greek and Latin codices $\left(4^{\text {th }}-8^{\text {th }}\right.$ centuries)

In practice, the $0.80(4 / 5)$ value coincides with the original proportions of an animal skin, ${ }^{51}$ or more precisely with those of its 'usable rectangle', which for anatomical reasons is naturally quite wide. It seems reasonable, therefore, to hypothesise that there was a passive tendency on the part of the artisans to work with a skin's natural proportions, and that they limited themselves to obtaining two, or

50 Since proportion is a more stable parameter and largely speaking not related to content, the risk of statistical distortions arising due to low numbers in the sample is reduced in this instance. 51 See Ansalone et al. 1993. For the 108 modern skins examined, whose measurements are reported on pp. 187-190, the average proportion of the usable rectangle is equal to 0.803 , with a maximum of 0.885 for large calf skins and a minimum of 0.654 for small lambskins. Goat and sheepskins register means of 0.815 and 0.779 respectively. The sizes of animals in medieval times can be considered comparable to those of today, as demonstrated by Bischoff / Maniaci 1995. 
at the most three, bifolia (also naturally wide) ${ }^{52}$ from each skin. Such bifolia were suitable for the manufacture of volumes of small to medium, or medium size.

In the centuries following the $6^{\text {th }}$, the Greek codex maintains, albeit to a lesser extent, a tendency towards wideness (a legacy of late antiquity), hence between the $9^{\text {th }}$ and $12^{\text {th }}$ centuries (and also during the $13^{\text {th }}$ ) proportions closer to $3 / 4(0.75)$ than $4 / 5(0.80)$ are seen. ${ }^{53}$ The $11^{\text {th }}$ century stands out as an exception in this context, since it is distinguished by (on average) larger size and a return to proportions closer to those of a square. ${ }^{54}$

In essence, in the Latin context there was (in the northern regions of Europe, at least) a clear evolutionary process oriented towards a rational solution which, in theory, made it possible to manufacture books of the same proportions regardless of their size, that is as long as skins were divided in the same way. However, this trend, which was already apparent in the $12^{\text {th }}$ century, was hampered in the Carolingian period by the fresh success of wider proportioned tomes, a success that was perhaps owed to an ideological and material influx of antigraphs dating from late antiquity on the preparation of new copies in minuscule. On the other hand, in the Greek context the trend is once again towards stability. One cannot explain the reasons lying behind this, apart from citing aesthetic concerns and an enduring respect for tradition, to which it would seem that the manufacturing procedures used for making quires (i.e. the subdivision of wide skins into two or three bifolia, which result in 'naturally' wide volumes), were subordinated.

52 It has been noted that a wide rectangle, if folded along its short axis, yields a succession of narrow surfaces (when a sheet of parchment is folded in-folio or in-8), or wide ones (when folded in-4). When a skin is cut into three pieces in 'T' form (in-6), the resulting three rectangles will naturally be wide (Maniaci 1999, 106).

53 In the absence of specific research on the material and structural characteristics of the Greek parchment codex in the Palaeologan Age, one can point to the proportions of late Byzantine volumes included in Sautel 1995, which lists the following values: $13^{\text {th }}$ century $=0.747$ (294 volumes); $14^{\text {th }}$ century $=0.729$ ( 80 volumes); $15^{\text {th }}$ century $=0.734$ ( 21 volumes).

54 See Maniaci 2002, 138-139, in which Tab. 3 shows that the maximum width of $11^{\text {th }}$-century codices is the same for both single and double column pages. 


\section{Layout of the text}

Apart from a few isolated cases of mise en page in three or four columns, in general the criteria applied when choosing between single column and double column pages confirm the more conservative character of Greek in comparison to Latin volumes (Tab. 5).

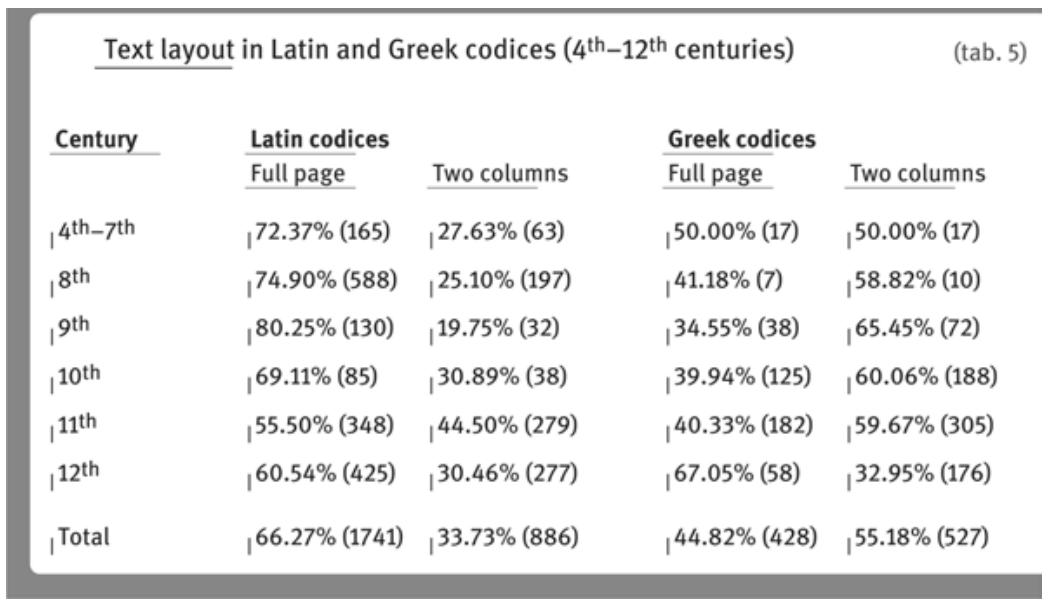

Tab. 5: Text layout in Latin and Greek codices $\left(4^{\text {th }}-12^{\text {th }}\right.$ centuries $)$

As has already been pointed out by Lowe, ${ }^{55}$ in Latin codices antiquiores the rate at which pages are laid out in two columns is almost 50\% in the most ancient examples, but undergoes a virtual collapse after the end of the $5^{\text {th }}$ century, when it decreases to only about a quarter of the total. The single column layout continues to predominate in the centuries subsequent to the $8^{\text {th }}$, even if it appears a lot less frequently from the $11^{\text {th }}$ century onwards.

In the Greek context the relationship between the two types of layout is entirely different: with the advent of minuscule script, the balance seen in the earliest centuries is replaced by a progressive affirmation of the two-column layout, a trend which culminates in the $11^{\text {th }}$ century. However, the following century is marked by a reversal of this trend, with the single column layout gaining the

55 Lowe 1925 (1970), 207; Lowe 1928 (1970), 59; John 1990, 100. 
upper hand.$^{56}$ Codices in majuscule script dating from the mid-Byzantine period, which are mostly liturgical in nature, are almost all laid out in two columns. ${ }^{57}$

Carla Bozzolo and Ezio Ornato have drawn attention to the relationship that links the choice of one or another of the layout options to a volume's size, as well as-but only in an obvious way from the $8^{\text {th }}$ century onwards - to the degree of page utilisation.

The relationship between the layout and dimensional characteristics of manuscripts can readily be verified by looking at a criterion which is most immediately and directly related to all the others, namely size (Tab. 6). The connection between the width of a book and the layout of its text is very clear even in the smallest of volumes, notwithstanding the greater success enjoyed by the two-column layout in the Greek context. In both book manufacturing traditions, the single column layout was almost always adopted for the creation of small volumes, whereas the two-column layout predominates in larger codices, even if it never fully prevails. It should be noted, however, that large volumes with single column layouts are more common than smaller volumes with twocolumn layouts. This shows that in the case of large format codices the shift to a two-column layout (in the Early Middle Ages) was not perceived as an absolute necessity, which conversely would be the case in Latin production (though not in Greek) in the $13^{\text {th }}$ to $14^{\text {th }}$ centuries..$^{58}$

The correlation between dimensions and layout is apparent from the very outset of the Greek and Latin codices' histories. As regards the latter, it is particularly evident in the subclass of codices written in uncial script, where the contrast between small single column and large two-column volumes is at its most conspicuous.

56 Connected, as will be explained shortly, to the reduction in size. See (below) the text corresponding to footnote 59 .

57 For the $9^{\text {th }}$ to $12^{\text {th }}$ centuries the ratio between the two layouts is $83 \%$ to $17 \%$ (186 against 37 of the 223 items evaluated).

58 In all periods one meets with exceptions to the prevailing trend which do not invalidate this view. The examples cited by Tristano 1991, 78-79, fully conform to the norm observed in Southern Italy. 
Relationship between size and text layout

in Latin and Greek codices ( $4^{\text {th }}-12^{\text {th }}$ centuries)

(tab. 6)

\begin{tabular}{|c|c|c|c|c|}
\hline \multirow[t]{2}{*}{ Century } & \multicolumn{2}{|l|}{ Latin codices } & \multicolumn{2}{|l|}{ Greek codices } \\
\hline & Full page & Two columns & Full page & Two columns \\
\hline $\mid<300$ & |97.85\% (91) & | $2.15 \%(2)$ & |10.00\% (10) & $0 \%(0)$ \\
\hline |300-349 & |93.83\% (152) & | 6.17\% (10) & |93.33\% (42) & $6.67 \%(3)$ \\
\hline |350-399 & |94.15\% (306) & |5.85\% (19) & |75.95\% (60) & |24.05\% (19) \\
\hline |400-449 & | 89.27\% (391) & |10.73\% (47) & ।73.79\% (76) & |26.21\% (27) \\
\hline |450-499 & | 82.67\% (396) & |17.33\% (83) & |69.31\% (70) & |30.69\% (31) \\
\hline 1500-549 & |59.95\% (250) & | $40.05 \%(167)$ & |49.21\% (62) & |50.79\% (64) \\
\hline |550-599 & |35.29\% (102) & |64.71\%(187) & |24.00\% (30) & |76.00\% (95) \\
\hline |600-649 & |21.00\% (42) & |79.00\% (158) & |22.22\% (20) & |77.78\% (70) \\
\hline |650-699 & $8.54 \%(7)$ & $91.46 \%(75)$ & |11.11\% (3) & |88.89\% (24) \\
\hline ।>700 & $2.82 \%(4)$ & |97.18\% (138) & |11.11\% (1) & |88.89\% (8) \\
\hline |Total & | $66.27 \%(1741)$ & |33.73\% (886) & |52.84\% (382) & |47.16\% (341) \\
\hline
\end{tabular}

Tab. 6: Relationship between size and text layout in Latin and Greek codices $\left(4^{\text {th }}-12^{\text {th }}\right.$ centuries)

In essence, with the first appearance of parchment manuscripts, both the Greek and the Latin artisans showed themselves to be perfectly aware of the possibility of breaking up excessively long lines of script so as to make them easier to read. Conversely, the two-column layout was not yet used to achieve another goal, namely a more intensive utilisation of the page. This would happen later on, in the Late Middle Ages, when the value of the 'ruling unit' (calculated by dividing the height of the written area by the number of lines it contains, minus one) could be very low. When this was the case, the large number of lines on the page, together with the large number of characters contained in lines of considerable length, made it necessary to 'split' the width of the written area. For this reason, starting in the $8^{\text {th }}$ century, it often happened that the 'ruling units' of two-column layouts were distinctly smaller than those of single column layouts in volumes of the same size.

In order to confirm the (again) very weak link that existed between page utilisation and layout in the Early Middle Ages, one has only to compare, in volumes of equal size, the means of ruling units in single column and two-column 
manuscripts. ${ }^{59}$ In the Latin context, the distance between lines is consistently shorter in two-column volumes, but the degree of variance is always quite small (ranging from a minimum of $0.48 \mathrm{~mm}$ in the $8^{\text {th }}$ century, to a maximum of 0.97 $\mathrm{mm}$ in the $12^{\text {th }}$ ). In addition, the highest value (though only by a millimetre or so) is generally lower than the values that would be reached in the succeeding centuries. ${ }^{60}$ In the case of the Byzantine codex, the adoption of a two-column layout did not confer any benefit vis-à-vis the utilisation of space, given that in volumes of equal size the average ruling unit remained almost identical in the two different types of layout (with a maximum variance of $0.23 \mathrm{~mm}$ in the $10^{\text {th }}$ century). The greater occurrence of the two-column layout in medium-sized volumes, which does not necessarily imply a more intense utilisation of the page, instead seems to be attributable to the passive and uninspired way in which working methods dating back to late antiquity were applied.

Having ascertained that, prior to the Late Middle Ages, the purpose of a twocolumn layout was not to increase the capacity of a page by compressing lines of text, we need to take into account the fact that the presence of an intercolumnar 'corridor' probably caused a loss of space that an artisan may (or may not) have felt the need to compensate for. In other words, the intercolumnar space could simply be 'cut through' a written area of exactly the same width as that of a single column manuscript, with a resulting loss of writable space. Alternatively, the gap could be created by 'stretching' the base of the rectangle allotted for the text, thereby reducing the width of either one or both of a page's lateral margins. An analysis of the relationship between the width of the written area and that of the page (Tab. 7) makes it possible to identify the solution employed: should the ratio be higher in two-column volumes, we shall deduce that the written area was deliberately 'widened', thereby sacrificing the internal and external margins (or only one of these), with the aim of recuperating all or part of the surface area lost through the introduction of the intercolumnar space. ${ }^{61}$

59 The variances are calculated by grouping volumes into $40 \mathrm{~mm}$ incremental classes, limited to centuries represented by more than five items for each layout type. Notwithstanding lacunae (in centuries preceding the $8^{\text {th }}$ above all), the variation between the two contexts is consistently higher, and can therefore be considered statistically significant.

60 A variation of $1 \mathrm{~mm}$ in a manuscript ruled in 30 lines makes it possible to gain $30 \mathrm{~mm}$ in a single column, which equates to approximately four lines of script. In the $8^{\text {th }}$ century, in volumes of identical size, the diminution of the 'ruling unit' would make it possible for a page to contain 40 , or perhaps even 50 , lines of text.

61 The almost total absence of data relating to the size of the intercolumnar space makes it impossible to carry out a more precise analysis. 


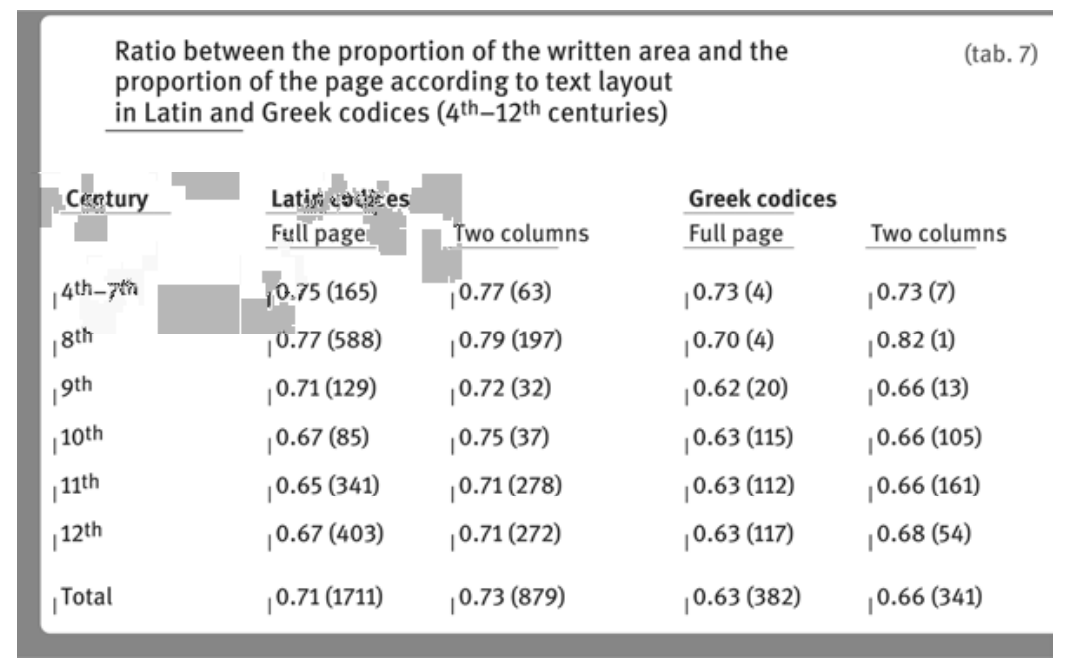

Tab. 7: Ratio between the proportion of the written area and the proportion of the page according to text layout in Latin and Greek codices $\left(4^{\text {th }}-12^{\text {th }}\right.$ centuries)

In actual fact, up until the $10^{\text {th }}$ century, in both the East and the West, page layout did not exert a significant influence on the width of the written area, which in two-column volumes shows only a slight increase. By contrast, in the centuries that followed, in the Latin context a new level of awareness on the part of the artisans led to their taking different approaches to the way in which the written area was established in relation to the overall layout. This consisted in increasing the width (and later on also the height) of the written area in two-column volumes, with the aim of avoiding, or at least mitigating, the reduction in the writable surface. ${ }^{62}$ Continuing to prefer working methods that originated from the earliest times, the Greeks applied compensating mechanisms in a more limited way, and at a later point. ${ }^{63}$

62 Up until the $8^{\text {th }}$ century, the written area of Latin codices expanded in a symmetrical way at the 'cost' of both the internal and the external margins (whose relationship is not influenced by the layout), whereas in the centuries that followed the 'cost' of the expansion was borne mostly by the internal margin. It would seem that the Greek codex evolved in the opposite way, namely towards a more equal distribution of the variation (which was in any event very slight), when the two types of layout are compared.

63 Maniaci 2002, 165, Table 8. 


\section{Criteria for the distribution of 'black' and 'white' areas on the surface of the page}

The positioning of text is just one of various aspects which combine to define the layout of a page and is determined by the amount of space allotted to the written area, by its form (either slender or more or less square), and by its placing within the available surface area (in other words, by the 'spatial configuration' of the four margins which combine to form its frame).

Overall, in all historical periods the pages of the Greek codex are distinctly less filled with script than those of Latin ones, as one can deduce from an analysis of the relationship between the written area and the total surface area of a page (a parameter conventionally referred to as 'page filling' [Tab. 8]). ${ }^{64}$

The gap, which is initially quite low, starts to increase at the beginning of the $8^{\text {th }}$ century (the period in which in both the East and the West page filling is high), only to decline again towards the end of the period under examination, when pages of the Latin manuscript start to become less text-laden, a phenomenon that represents the beginning of a tendency that would continue in the following centuries.

This trend is in total contrast to the stability of the Greek codex, in which the average page filling value remains substantially unchanged until the $12^{\text {th }}$ century. ${ }^{65}$

64 The classic reference is to Bozzolo et al. 1984.

65 The analysis of the 'black' should be expanded by taking into account the manuscripts' content. For information limited to the mid-Byzantine codex, see Maniaci 2002, 263-265, in which lower levels of page filling are observed in the production of manuscripts of biblical, liturgical and homiletic content. 
Average of page filling of Latin and Greek codices ( $4^{\text {th }}-12^{\text {th }}$ centuries)

(tab. 8)

Century
$1^{4^{\text {th }}-7 \text { th }}$
$1^{\text {th }}$
$1^{\text {th }}$
$1^{10^{\text {th }}}$
$1^{11^{\text {th }}}$
$1^{12^{\text {th }}}$
$1^{\text {Total }}$

$$
\begin{aligned}
& \text { Latin codices } \\
& \text { Full page Two columns Total } \\
& \text { |0.575(165) , } 0.574(63) \quad, 0.572(228) \\
& \text { |0.624(588) , } 0.637(197) \quad, 0.627(785) \\
& \text {,0.532(129) , } 0.558(32) \quad, 0.538(161) \\
& \text { |0.503(85) } \quad 0.580(37) \quad, 0.526(122) \\
& \text {,0.492(341) , } 0.544(278) \quad, 0.515(619) \\
& \text { |0.506(403) }, 0.534(272), 0.517(675) \\
& \text { |0.552(1711) }, 0.566(879), 0.557(2590)
\end{aligned}
$$

\section{Greek codices}

Full page Two columns Total

|0.545(4) $\quad 0.538(7) \quad, 0.540(11)$

|0.528(4) $\left.\quad\right|^{0.719(1) \quad, 0.566(5)}$

| $0.431(20) \quad, 0.487(13) \quad, 0.453(33)$

|0.448(115) $, 0.466(105) \quad, 0.457(220)$

| $0.444(122), 0.467(161) \quad, 0.457(283)$

|0.447(117) $\quad 0.485(54) \quad, 0.459(171)$

|0.447(382) $, 0.472(341) \quad, 0.459(723)$

Tab. 8: Average of page filling of Latin and Greek codices $\left(4^{\text {th }}-12^{\text {th }}\right.$ centuries)

As far as the proportion of the written area is concerned, this is necessarily correlated to the page's proportion so as to preclude the possibility of a displeasing aesthetic effect caused by the written area being much narrower or much wider than the page it is placed on.

The ideal situation would call for parity between the two proportions; however, this only occurs in both Latin and Greek codices in late antiquity, a period in which the written area is characterised, like the page, by a particularly large set-up. ${ }^{66}$ Starting in the Early Middle Ages, the proportion of the written area tended to become narrower, and stabilised at values that were always lower than those of the book, with the difference remaining almost constant in the East and the West until the end of the $12^{\text {th }}$ century (Tab. 9).

66 Lowe 1925 (1970), 207 (202 of the reprinted version) had already listed the square proportioning of the written area among the various 'symptoms' of antiquity; he then extends the criterion more generically to include 'nearly square' proportions (Lowe 1928 [1970], 59 [270 of the reprinted version]). 

the page in Latin and Greek codices ( $4^{\text {th }}-12^{\text {th }}$ centuries)

\begin{tabular}{|c|c|c|}
\hline Century & Latin codices & Greek codices \\
\hline $1^{4^{\text {th }}-7^{\text {th }}}$ & $\mid-0.011$ & |nd \\
\hline $8^{\text {th }}$ & 0.022 & 0.013 \\
\hline $1^{9^{\text {th }}}$ & 0.033 & |0.073 \\
\hline $1^{10^{\text {th }}}$ & | 0.059 & $\left.\right|^{0.071}$ \\
\hline$\left.\right|^{11^{\text {th }}}$ & 0.065 & |0.059 \\
\hline $1^{12^{\text {th }}}$ & 0.056 & 0.057 \\
\hline | Total & | 0.041 & |0.062 \\
\hline
\end{tabular}

Tab. 9: Difference between the proportion of the written area and the page in Latin and Greek codices $\left(4^{\text {th }}-12^{\text {th }}\right.$ centuries)

If the correlation between the proportion of the written surface and that of an individual codex is roughly the same in both manuscript traditions, by contrast the positioning of the written area on the page-determined by the 'hierarchy' of the four margins-answers to a different set of construction principles, as demonstrated by an examination of the distribution of the margins and, in particular, a comparison-which is simple to perform-of the overall breadth of the two opposite pairs, composed of, respectively, the external margin coupled with the lower margin, and the internal margin coupled with the upper margin (Tab. 10). ${ }^{67}$

67 The usable sample is limited to a little over 400 items for the Latin context, while the Greek one, predominantly composed of codices whose page sizes were all directly measured, numbers approximately 700 . Since the $C L A$ do not register the dimensions of margins and the data available on the Greek codices is too limited, it is not possible to analyse the positioning of the written area in the earliest times. 
Ratio between the two opposite pairs of margins

(mest $+\operatorname{minf} /$ msup + mint) in Latin and Greek codices $\left(4^{\text {th }}-12^{\text {th }}\right.$ centuries)

Century Latin codices

Full page Two columns Total |nd and -

1.87 (19) , 1.86 (25)

1.92(40) , |1.94 (47)

|1.70(14) , |1.61(6) , 1.67(20)

|1.96 (47) | 2.22(21) | 2.04 (68)

|2.20 (154) |2.19 (2.20 (247)

|2.07(274) |2.15(133) |2.09(407)
Greek codices

Full page Two columns Total

|1.28 (1) , 1.16

|1.05 (2) , 1.40 (1)

|1.62 (19) , 1.75 (12)

|1.53 (115) |1.57 (101)

| 1.55 (216)

| 1.60 (122) , |1.59 (283)

|1.60(117) |1.62(54) , 1.61(171)

|1.58(376) , $1.59(330) \quad, 1.58(706)$

Tab. 10: Ratio between the two opposite pairs of margins (mest + minf / msup + mint) in Latin and Greek codices $\left(4^{\text {th }}-12^{\text {th }}\right.$ centuries)

While in the Greek codex the relationship between the two pairs remains essentially unchanged over time, registering a value of 3 to 2 (1.5) in favour of the most 'exposed' margins (i.e. the external and lower ones), in the Latin context the space that these occupy, which was already greater starting from the $8^{\text {th }}$ century, increases further over the course of time, and ultimately reaches a total size that is more than double than that of the other pair of margins.

Associated with this change, in the $11^{\text {th }}$ century only the Latin codices exhibit a clear reduction in the width of the upper margin in relation to the total height of the page. In other words, the written area tends to become progressively more distant from the most exposed margin areas, and in particular from the lower margin (the so-called 'footer'). ${ }^{68}$ This phenomenon is not seen in the Greek sample which, once again, is distinctly more stable in this regard (Tab. 11).

68 Conversely, the relationship between the internal margin and the width of the page remained essentially unchanged over time, probably on account of a dearth of available space. 
Ratio between top margin and page height (msup/H) in Latin and Greek codices ( $4^{\text {th }}-12^{\text {th }}$ centuries)

Century
$1^{4^{\text {th }}-7^{\text {th }}}$
$1^{\text {th }}$
$1^{\text {th }}$
$1^{10^{\text {th }}}$
$1^{\text {th }}$
$\left.\right|^{\text {Total }}$

\begin{tabular}{|c|c|c|}
\hline \multicolumn{3}{|c|}{ Latin codices } \\
\hline Full page & Two columns & Total \\
\hline |nd & , nd & - \\
\hline 9.73(20) & $8.95(6)$ & |9.55 (26) \\
\hline 9.52 (40) & 10.12 (7) & 9.61(47) \\
\hline |10.18 (14) & $9.29(6)$ & |9.91(20) \\
\hline $8.67(47)$ & |7.11 (21) & $8.18(68)$ \\
\hline 8.19 (154) & |7.94 (93) & $8.10(247)$ \\
\hline $8.68(274)$ & 8.03 (133) & 8.47 (407) \\
\hline
\end{tabular}

Greek codices

Full page Two columns Total

|15.00(1) , 14.84(1) , 14.92 (2)

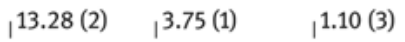

|11.99(19) , , 10.89 (112) , (31)

|12.06(115) , 11.88(101) , 11.97(216)

|12.44(122) , 12.32(161) |12.37(283)

|12.42(117) , 11.77(54) , |12.21(171)

|12.31(376) ,12.02(330) ,12.17(706)

Tab. 11: Ratio between top margin and page height (msup/H) in Latin and Greek codices $\left(4^{\text {th }}-\right.$ $12^{\text {th }}$ centuries)

The idea that the tendency to decentralise the written area in relation to the overall page surface-a very widespread phenomenon which persists even today and can be seen in the best contemporary typesetting ${ }^{69}$ - can be explained by the desire to protect the text as much as possible from the negative impact of lisières is though-provoking, but would only be applicable in cases where the bifolia were obtained by folding skins symmetrically, either in in- 4 or in-8. This possibility would not be incompatible with a previous and perhaps more convincing (but likewise impossible to prove) hypothesis that the greater width of the external and lower margins could have served to make it easier to hold an open book in a way that limited, or even eliminated the possibility of the written surface coming into contact with the user's fingers.

However one chooses to interpret the two hypotheses, the positioning of the written area on the page represents the governing principle behind the (few) sets of instructions or 'recipes' which have come down to us-two in Latin, two in vernacular, and one in Greek (which is, in fact, a detailed 'mock-up' or 'framework' intended for the preparation of an individual volume containing Aristotelian

69 See, for example, the templates suggested by Fioravanti 2002, 186-189. 
material with an added commentary). With a sole exception, almost all the surviving sources refer to late or post-medieval book production. ${ }^{70}$

In a different setting, I intend to carry out a comparative study of the stipulations set out in the 'recipes'-prescriptions that have previously been separately addressed in individual studies, but which have never been afforded an overall evaluation-by analysing the basic principles underlying the compilation of each of them, and by ascertaining the true extent of their diffusion, as I have previously done with two Latin texts. Accordingly, here I shall limit myself to focusing on two stipulations regarding the width of margins, which in the Western 'recipe' are distributed differently. (For reasons that I will explain elsewhere, to my mind the Sigismondo Fanti's text is open to an interpretation different to that proposed by Giorgio Montecchi.) ${ }^{71}$ (Tab. 12).

70 Here, I shall confine myself to summarising the surviving sources that contain the relevant 'recipes', their approximate dates and the main contributions dealing with them (to which I refer for further details on the texts): (1) the 'Saint-Remi' recipe, Paris, Bibliothèque Nationale, Par. lat. 11884, $10^{\text {th }}$ century, in Latin (Muzerelle 1989; Maniaci 1995); (2) the 'Munich' recipe, München, Bayerische Staatsbibliothek, Clm $7775,15^{\text {th }}$ century, in Latin (Bischoff 1984; Maniaci 1995); (3) the 'Vatican' recipe, Città del Vaticano, Biblioteca Apostolica Vaticana, Vat. lat. $4825,15^{\text {th }}$ century, in vernacular (Cherubini 2004); (4) the 'Sigismondo Fanti's recipe, 16 ${ }^{\text {th }}$ century (c.1514), in vernacular (Montecchi 1997 [1994]); (5) the 'Greek' recipe, Città del Vaticano, Biblioteca Apostolica Vaticana, Vat. gr. 604, ff. 183r-187r, $14^{\text {th }}$ century (Bianconi 2010). The Arabic 'recipe' that survives in a very likely corrupted form lies outside our area of interest: see the Paris codex, Bibliothèque nationale, Par. ar. $6844,13^{\text {th }}$ century (Déroche et al. 2000, 179). The so-called diagram drawn by the $13^{\text {th }}$-century Piccardian architect Villard de Honnencourt, which is preserved in a 'notebook', Paris, Bibliothèque nationale, Par. lat. 19093, is not in fact a 'recipe', but rather a graphic representation of a system for the subdivision of any segment into equal parts, starting out from a rectangle (see Tschichold 1965, and Tschichold 1975). Only when this contribution had already been prepared for publication did I come across Tristano 2010: in the essay, dedicated to the stipulations of $15^{\text {th }}$-century calligraphy, Fanti's directions for the mise en page (81-88) are also taken into consideration (based on the interpretation by Montecchi).

71 The reconstruction proposed by Montecchi-taken up by Agati 2009, 229-232, and by Cherubini 2004, 250-252, produces-'results which do not tally [...] with any of the 'recipes' that have been noted up to the present' (ibid., 252). My alternative hypothesis rests on a different interpretation of the instructions issued for the setting-up of the external margin: tu die partire quello che avanza del quadro in giù et quello mezo $\grave{e}$ lo spacio di fuori, which I am inclined to believe refers not to the width of the lower margin (identified in a very muddled way), but rather to the difference between the height of the page and the square constructed based on the width of the written area. 
Amplitude in $\%$ of the four margins according to the preserved layout 'recipes' in Greek and Latin codices ( $4^{\text {th }}-12^{\text {th }}$ centuries)

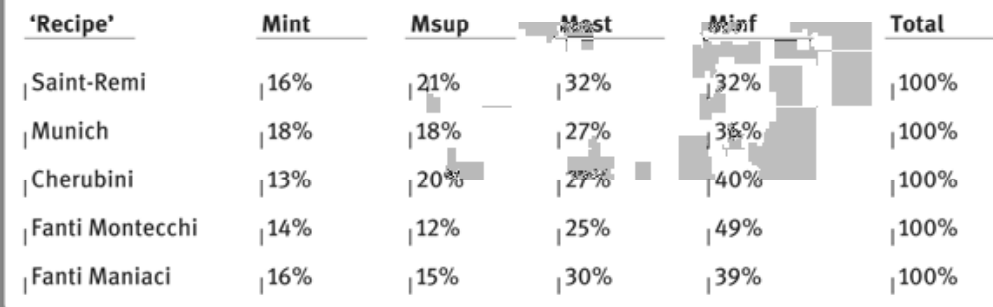

Tab. 12: Amplitude in \% of the four margins according to the preserved layout 'recipes' in Greek and Latin codices $\left(4^{\text {th }}-12^{\text {th }}\right.$ centuries)

The surviving 'recipes' document the use of various page construction principles. The two most ancient ones both require that one pair of margins be equal in breadth (in the Remigian 'recipe' the external and lower margins; in the Munich 'recipe' the internal and upper margins). The first of the vernacular texts stipulates that the margins be arranged in an ascending progression, whilst the governing principle behind Fanti's recommendations seems rather less clear, no matter how one 'deciphers' his instructions. In any event, the actual degree of application of the various relationship series can be confirmed, in a preliminary analysis, by applying a simple test based on an estimate of the width of each margin, expressed as a percentage in relation to the margins' overall width. By calculating the four percentages for all the codices and comparing each of the values obtained with those prescribed in the 'recipes', one can calculate the sum of the distances, thus making it possible to identify (with an acceptable degree of accuracy), the likely application of a given 'recipe', when the sum does not exceed 7\%. For each century, the percentage of volumes which satisfy this condition represents the 'good fortune' (or otherwise) enjoyed by the various 'recipes' (Tab. 13). ${ }^{72}$

72 The absence (in the Latin codices) and the scarcity (in the Greek) of information on the widths of margins precludes the possibility of extending the verification procedure to the previous centuries. 
Percentages of adaptation of Latin and Greek codices

(tab. 13) to layout 'recipes'

\begin{tabular}{|c|c|c|c|c|c|}
\hline Century & Saint-Remi & Munich & Cherubini & Fanti Montecchi & Fanti Mani \\
\hline \multicolumn{6}{|c|}{ Latin codices } \\
\hline $4^{\text {th- }}-7^{\text {th }}$ & Ind & Ind & Ind & Ind & Ind \\
\hline $8^{\text {th }}$ & $10 \%$ & $10 \%$ & $10 \%$ & $10 \%$ & $10 \%$ \\
\hline $9^{\text {th }}$ & $14.26 \%$ & $10 \%$ & $10 \%$ & $0 \%$ & $10 \%$ \\
\hline $10^{\text {th }}$ & |15.79\% & , $0 \%$ & $10 \%$ & $0 \%$ & $5.26 \%$ \\
\hline $11^{\text {th }}$ & | $7.46 \%$ & |2.99\% & $10 \%$ & $10 \%$ & |13.43\% \\
\hline $12^{\text {th }}$ & $6.07 \%$ & $5.67 \%$ & $0 \%$ & $0.40 \%$ & $14.17 \%$ \\
\hline
\end{tabular}

\section{Greek codices}

\begin{tabular}{|c|c|c|c|c|c|}
\hline $4^{4^{\text {th }}-7^{\text {th }}}$ & Ind & |nd & | nd & |nd & |nd \\
\hline $8^{8 \text { th }}$ & $10 \%$ & $10 \%$ & $10 \%$ & $0 \%$ & $0 \%$ \\
\hline $1^{9^{\text {th }}}$ & $3.23 \%$ & $3.23 \%$ & $10 \%$ & $0 \%$ & $3.23 \%$ \\
\hline $1^{10^{\text {th }}}$ & |15.28\% & । $4.63 \%$ & |0.93\% & । $0 \%$ & | $0.46 \%$ \\
\hline $1^{11^{\text {th }}}$ & |19.79\% & $4.59 \%$ & 1.06\% & । $0 \%$ & |0.71\% \\
\hline $1^{12^{\text {th }}}$ & |23.98\% & |4.09\% & 1.17\% & $0 \%$ & |1.17\% \\
\hline
\end{tabular}

Tab. 13: Percentages of adaptation of Latin and Greek codices to layout 'recipes'

As I have already demonstrated elsewhere ${ }^{73}$ the Greek manuscripts unexpectedly provide proof of a close kinship with the Saint-Remi recipe ${ }^{74}$, which on the other hand is not well suited for application in Latin book production. With regard to the three later prescriptions, predictably enough these turn out to be completely alien to the manufacture of the Medieval parchment manuscript, with the sole (partial) exception of Sigismondo Fanti's $17^{\text {th }}$-century recipe, if one is prepared to accept my

73 Maniaci 1995, 31-32.

74 Bearing in mind the numerous uncertainties which hamper verification (about which see ibid., 2223 ), the value of $24 \%$ recorded for the $12^{\text {th }}$ century should be considered particularly high. Conversely, the low percentage recorded for the $9^{\text {th }}$ century is probably influenced by the relatively small number of items included in the sample. Giovanna Menci's attempt (Menci 1997) to detect in the layout of Greek papyrus rolls traces of an antecedent taste which subsequently 'flowed into' the Saint-Remi 'canon' is not convincing. 
re-reading of it. The quest for other canonical rules, of which there seems to be no trace in the surviving documentation, has so far been in vain. ${ }^{75}$

\section{Exploitation of the written area}

Just as in the case of the geometric criteria applied when setting-up a page, its capacity was determined by the amount of text inserted within the area allotted to accommodate it. As is well known, a copyist had various strategies at his disposal to 'calibrate' the density of text, and these could be combined when necessary. He could adjust the interlinear space, the module and the horizontal compression/expansion of script, and the frequency and severity of any abbreviations employed. In the absence of the relevant data necessary to carry out an in-depth investigation, a rough calculation of the number of characters per line (carried out on originals or facsimiles, or gleaned from surveys already carried out by others) can in any event provide some indications useful for assessing the degree to which the space allotted to host the script is exploited. Indeed, the product of the total number of characters counted in a single line divided by the total number of lines provides an estimate of the amount of text accommodated by a single page (Tab. 14$).{ }^{76}$

75 In particular, with regard to the texts created by hypothesising the application (starting from the internal margin) of relationships in progressions of 10-20-30-40 and 12-12-38-38, the research has yielded practically nothing of significance. For the Latin codices alone, the percentages obtained by applying the sequence 15-15-35-35 are a little higher, but are in any event still lower than 10\%.

76 The count, which had previously been carried out on the original Greek codices, was performed from scratch on the reproductions contained in the CLA, which (in a forward-looking way) almost invariably reproduce the entire breadth of the written area. The calculation, which is per force very approximate, consistently includes all notation of any kind placed on lines (excluding spaces). It was not possible to extend the evaluation to the size of the script-the width of characters in particular-which would have called for an ad hoc surveying campaign. It is worthwhile to point out that the means reported in Table 13 are influenced by the size distribution of volumes in the various historical periods, but that the observed chronological evolution is also confirmed within the individual size ranks. 
Evolution of the average page capacity

in Latin and Greek manuscripts ( $4^{\text {th }}-12^{\text {th }}$ centuries)

\begin{tabular}{|c|c|c|c|c|c|}
\hline \multicolumn{3}{|c|}{ Latin codices } & \multicolumn{2}{|c|}{ Greek codices } & \multirow[b]{2}{*}{ Ruled lines } \\
\hline $\begin{array}{l}\text { Characters } \\
\text { per page }\end{array}$ & $\begin{array}{l}\text { Characters } \\
\text { per line }\end{array}$ & Ruled lines & $\begin{array}{l}\text { Characters } \\
\text { per page }\end{array}$ & $\begin{array}{l}\text { Characters } \\
\text { per line }\end{array}$ & \\
\hline 909 (229) & 33.44 (230) & |26.42(231) & |691(8) & |24.38(8) & |23.83 (33) \\
\hline 1188 (785) & | 41.96 (785) & |27.02 (794) & |1138 (7) & |29.57 (7) & |34.81 (17) \\
\hline $1252(64)$ & |45.52 (78) & | 28.38 (165) & |1005 (42) & |34.57 (43) & |27.47 (110) \\
\hline 1414 (37) & | $46.97(59)$ & 28.75 (126) & 1153 (227) & 37.09 (231) & |29.69 (313) \\
\hline |1423 (167) & |44.76 (191) & |31.86 (629) & |1106 (281) & 37.41 (283) & 28.25(305) \\
\hline 1782 (251) & |50.79 (317) & $33.04(725)$ & 1096 (170) & |39.49 (172) & |27.67 (176) \\
\hline |1277 (1533) & | 43.73 (1660) & |29.91(2670) & |1108 (735) & $36.72(744)$ & 28.48(954) \\
\hline
\end{tabular}

Tab. 14: Evolution of the average page capacity in Latin and Greek manuscripts ( $4^{\text {th }}-12^{\text {th }}$ centuries)

Roughly speaking, when evaluated in this way, the overall exploitation of the page in Latin codices shows a clear tendency to increase over time. This increase is determined by a concomitant increase in the number of characters aligned on a single line and of the number of lines ruled on to a single page.

The reason for the growth that occurred after the $7^{\text {th }}$ century (which was in fact heralded by developments during the course of the $6^{\text {th }}$ ) can largely be attributed to the abandoning of capitals, and therefore of uncial script, in favour of a fully and definitively formed minuscule script. In fact, in contrast to that of the majuscule, the morphology of minuscule script allowed for a gain of about $30 \%$, mostly due to the increase in capacity of single lines, and somewhat less so to the increase in the number of lines on a page, which only becomes apparent in manuscripts of larger dimensions (i.e. measuring more than $500 \mathrm{~mm}$ ) written in minuscule. Additionally, in minuscule book production the capacity of individual pages increases by about 35\% between the early centuries of the Middle Ages and the $12^{\text {th }}$ century. Overall, if one considers on the one hand the volumes in uncial script of the $4^{\text {th }}$ to $8^{\text {th }}$ centuries, and on the other volumes produced in the $12^{\text {th }}$ century, a general tendency for the script's spatial performance to increase appears in volumes of the same dimensions, and in some cases it can even improve by some 75\% (i.e. in codices ranging in size from 400 to $600 \mathrm{~mm}$ ) (Tab. 15). 


\begin{tabular}{|c|c|c|c|c|c|c|}
\hline \multirow[t]{2}{*}{ Century } & \multicolumn{3}{|c|}{ Capital or Uncial } & \multicolumn{2}{|l|}{ Minuscule } & \multirow[b]{2}{*}{ Ruled lines } \\
\hline & $\begin{array}{l}\text { Characters } \\
\text { per page }\end{array}$ & $\begin{array}{l}\text { Characters } \\
\text { per line }\end{array}$ & Ruled lines & $\begin{array}{l}\text { Characters } \\
\text { per page }\end{array}$ & $\begin{array}{l}\text { Characters } \\
\text { per line }\end{array}$ & \\
\hline $1^{<300}$ & |433(14) & |24.36 (14) & | 17.29 (14) & |773 (53) & 33.65 (57) & 22.34 (61) \\
\hline$\left.\right|^{300-399}$ & 643(40) & $28.45(40)$ & $22.06(40)$ & 1002 (213) & |39.51(232) & 24.94 (271) \\
\hline |400-499 & 959 (140) & |34.55 (140) & |26.42 (140) & 1196 (434) & |42.70 (459) & 27.58(526) \\
\hline |500-599 & 955 (122) & |34.88 (122) & $\left.\right|^{26.82(122)}$ & 1628(303) & | 50.11 (349) & $31.57(402)$ \\
\hline |600-699 & |1169 (30) & |37.83 (30) & |29.63(30) & |2122 (99) & |56.57 (110) & 35.87 (158) \\
\hline |>700 & 1789 (6) & |48.67 (6) & $35.58(6)$ & |2437 (46) & 154.93 (54) & | 44.04 (101) \\
\hline |Total & 933(352) & 34.09 (352) & 26.13 (352) & |1384 (1148) & |45.31 (1261) & | 29.91 (1519) \\
\hline
\end{tabular}

Tab. 15: Average capacity of Latin codices depending on the graphic type and size

In the Greek context, the situation, once again, is different (Tab. 16).

\begin{tabular}{|c|c|c|c|c|c|c|}
\hline \multirow{3}{*}{ Century } & capacity o & f Greek codi & es dependin & in the graphic $t$ & type and size & (tab. 16) \\
\hline & \multicolumn{3}{|c|}{ Capital or Uncial } & \multicolumn{2}{|l|}{ Minuscule } & \multirow[b]{2}{*}{ Ruled lines } \\
\hline & $\begin{array}{l}\text { Characters } \\
\text { per page }\end{array}$ & $\begin{array}{l}\text { Characters } \\
\text { per line }\end{array}$ & Ruled lines & $\begin{array}{l}\text { Characters } \\
\text { per page }\end{array}$ & $\begin{array}{l}\text { Characters } \\
\text { per line }\end{array}$ & \\
\hline $1^{<300}$ & $627(2)$ & $25.00(2)$ & | $24.50(5)$ & | $685.76(18)$ & | 30.44 (18) & | $21.17(18)$ \\
\hline |300-399 & $\left.\right|^{576(9)}$ & |23.89 (9) & $\left.\right|^{23.89(34)}$ & | 894.59 (117) & $\left.\right|^{33.00(120)}$ & $\left.\right|^{25.38(120)}$ \\
\hline |400-499 & |693 (17) & | 27.00 (17) & $\left.\right|^{24.67(95)}$ & 1084.33 (192) & | 37.23 (195) & | 27.79 (195) \\
\hline |500-599 & |715 (29) & | $27.17(29)$ & $\left.\right|^{27.17(111)}$ & |1231.11(230) & |39.28 (231) & |30.35 (231) \\
\hline |600-699 & |1469 (7) & |39.86 (7) & |29.19(33) & |1344.53 (105) & |40.14 (107) & $\left.\right|^{32.04(107)}$ \\
\hline |>700 & 1485 (2) & $38.50(2)$ & $1^{48.00(3)}$ & |1953.05 (10) & $\left.\right|^{47.17(10)}$ & $\left.\right|^{36.70(10)}$ \\
\hline |Total & |791(66) & $28.30(66)$ & |25.71(281) & 1144.44 (672) & $37.60(681)$ & $28.86(681)$ \\
\hline
\end{tabular}

Tab. 16: Average capacity of Greek codices depending on the graphic type and size 
Despite the numerical sparseness of the sample, above all the figures clearly demonstrate that the overall spatial performance of the Greek manuscripts in majuscule is inferior to that of those produced in uncial script. As a result, the shift from majuscule to minuscule script proved highly advantageous in the Byzantine codex. That being said, the constant increase in the capacity of the page that occurred between the Carolingian era and the $12^{\text {th }}$ century is counter-posed in the Byzantine context, with the establishment of the minuscule script, by a marked stability (commencing in the $9^{\text {th }}$ century) of average levels of text density, which are in any event lower than those seen in the Western codex. Subsequently, the variation between the two traditions tends to increase substantially in the successive centuries. ${ }^{77}$

What conclusions, then, can be drawn from the general trends identified up to this point? As regards the logic that governs the mise en page of Eastern and Western codices, much work certainly remains to be done in the form of research focused on specific historical eras, manufacturing contexts, circulation and use, and text and script typologies. From this perspective, the results of the present study are limited to sketching out, at a macroscopic level, the main changes that occurred in the Greek and Latin manuscript production contexts between late antiquity and the Early Middle Ages, and 'signposting' some promising directions which ought to be further investigated. In the case of the Latin West, the geographical differences in production criteria used for the planning and realisation of the written page, and the 'trickling down' of innovations from the north towards the south, still have to be more clearly defined. Further investigation of the distinctive features of some areas (Insular manuscripts in particular) and the positive effect of the use of minuscule script-Carolingian minuscule above all-on the exploitation of the page is also required. Meanwhile, the Greek context is still lacking, among other things, adequate characterisation of the layout of codices in majuscule script and associated variations, which depend on a given manuscript's writing and content.

77 Considerable differences have come to light which divide the sample according to the specific content of works. Among the most conspicuous of the divergences observed is the consistently less efficient utilisation of space in volumes containing biblical and liturgical texts, as opposed to the greater text density associated with patristic, theological and secular manuscripts. More detailed information will only be obtained once more specific investigations of individual eras and contexts have been carried out. 
When compared, the similarities and, above all, 'structural' differences that emerge at around the beginning of the $7^{\text {th }}$ century in Latin and Greek codices, in both the construction and the management of the page, become more apparent and significant. If the size of volumes, which is dependent on the characteristics of the raw materials used in their creation, shows similar arithmetic means and steadily evolves, in both production contexts, from an 'automatic' preference for a medium-sized format towards a greater variety of sizes, it is also clear that the Greek codex does not include monumentality among its communication strategies.

Far more striking are: variations in the proportion of volumes (a parameter that has no direct relationship with the practical representational function of a book, but one which is in any event indicative of the artisans' level of technical know-how); choices vis-à-vis the single or two-column layout; standards of pagefilling; and the exploitation of the written area. In all cases, it seems to be possible to confirm a sharp contrast between the Latin artisans, who gradually become ever more 'evolved' and open to experimentation, and the Greek, who are decidedly more 'static' and remain firmly attached to techniques originating from the distant past-techniques that are well represented by the wide diffusion of canonical models of, in all likelihood, late antique ancestry, handed down over time through the 'recipe of Saint-Remi'.

As has already been noted, the differences seen over the long term in the mise en page are confirmed by various other material and structural characteristics, namely the Greek codex's protracted adherence to blind ruling, as opposed to the innovative introduction of colour in the Latin context; the almost exclusive persistence of the quaternion, as opposed to a much greater degree of variation seen in the late medieval Latin context; and the opening of quires, always starting with the flesh side in the Greek context, but in the Latin context alternating over the centuries. To these examples of different strategic choices, which demonstrate the more conservative nature of the Greek book, we can add others of less obvious significance, such as the speed-apparently different-at which the shift from the 'old style' to the 'new style' of blind ruling occurred, and the much wider variety of Greek ruling types employed in comparison to Latin ones. All things considered, the mise en page of the Greek book in the mid-Byzantine period-in common with other features of its manufacture-reflects an overall consistency in production and stability of form over the centuries, and little inclination to experiment in order to simplify the production of books and optimise their script capacity, at the same time as preserving their functionality. This is a picture which is entirely consistent with a 'world of scattered writers/scribes and writing places', ${ }^{78}$ characterised by the

78 Cavallo 1995, 76. 
presence of actors and organisational approaches that were largely speaking different from the dominant monastic and episcopal scriptoria that constituted the norm in the Early Latin Middle Ages.

\section{Discussion of Maniaci's intervention}

Kujawinski: First and foremost, thank you for providing us with such a highly informative account of the 'management' of the manuscript page. The question I would like to ask regards an issue that you have previously addressed in other settings, namely the relationship between the bifolia found in manuscripts today, and the original sheets of parchment from which they were sourced. The particular issue that interests me is the position of the dorsal axis in bifolia sourced from the central part of a skin and which were then folded in two. I would like to ask whether, based on your most recent surveys, the decision to fold a bifolia perpendicular to, or parallel with, the dorsal column was automatically influenced by the dimensions of the bifolia, in accordance with the specific procedure used for the subdivision of skins (either symmetrically or in-6), as is commonly stated in various studies carried out up till now, or alternatively whether other factors might have influenced this choice.

Maniaci: As regards volumes of the dimensions studied by you, the folding of the skin in-folio (confirmed by the position of the dorsal line), not only is the simplest solution, but is also the only one possible (folding-or subdivision-in-4 would require the availability of skins of far greater size than those of the kids or lambs that were normally used for the manufacture of parchment in the Late Middle Ages). In earlier times, the mixing of subdivided skins using various methods (not necessarily based on folding) even within the same codex (and also in very large format volumes, such as Atlantic Bibles) is an entirely unexceptional fact, and one which should be investigated in a more systematic way.

Ferrari: Thank you for your interesting and well-researched presentation. I would like you to clarify something for me. The dimensions of the codices included in your analysis are those of today: in other words, those which resulted from the trimming of margins during rebinding operations. My question is: do you think the greater width observed in the margins of the Greek manuscripts could be the result of a possible tendency in the Greek world to subject codices to less frequent 
rebinding operations than their Latin counterparts have been subjected to? Or is it possible that the Greek rebinding methods resulted in manuscripts being less drastically trimmed than was the case with the Latin methods?

Maniaci: Regarding the attitudes of the Greek binders vis-à-vis trimming, I am not able to provide you with any information, and I do not think any specific sources of information exist. In any event, the variation that distinguishes the Greek from the Latin codices, in terms of the percentage of 'black' or 'page filling', is too great and consistent over time to allow it to be attributed exclusively to a different frequency, and hence to different degrees of impact resulting from trimming operations. I am therefore inclined not to overestimate the significance of this factor.

\section{References}

Agati, Maria Luisa (2009), Il libro manoscritto. Da Oriente a Occidente. Per una codicologia comparata, Roma: L’Erma di Bretschneider (Studia archeologica, 166).

Aland, Kurt et al. (1994 [1963]), Kurzgefasste Liste der griechischen Handschriften des Neues Testaments, Berlin, New York: De Gruyter (Arbeiten zur neutestamentlichen Textforschung, 1) (originally published in 1963).

Andrist, Patrick / Canart, Paul / Maniaci, Marilena (2013), La syntaxe du codex. Essai de codicologie structurale. Turnhout: Brepols (Bibliologia, 34).

Ansalone, Mario et al. (1993), Caractérisation matérielle du parchemin moderne, in Maniaci, Marilena / Munafò, Paola F. (eds), Ancient and Medieval Book Materials and Techniques (Erice, 18-25 September 1992), I-II, Città del Vaticano: Biblioteca Apostolica Vaticana (Studi e Testi, 357-358), I, 185-225.

Bianchi, Francesco et al. (1993), 'La structure matérielle du codex dans les principales aires culturelles de l'Italie du XI' siècle', in Maniaci, Marilena / Munafò, Paola F. (eds), Ancient and Medieval Book Materials and Techniques (Erice, 18-25 September 1992), Città del Vaticano: Biblioteca Apostolica Vaticana (Studi e Testi, 357-358), II, 363-456.

Bianconi, Daniele (2010), 'Sources écrites et stratégies de mise en page à Byzance. À propos d'une recette pour l'Organon d'Aristote', in Jacob, Christian (ed.), Lieux de savoir, II. Les mains de l'intellect, Paris: Albin Michel, 401-425.

Bischoff, Bernhard (1984), 'Zur Schreib- und Buchtechnik des Spätmittelalters, II. Regeln für die Seiteneinteilung (Fünfzehntes Jahrhundert)', in Bischoff, Bernhard (ed.), Anecdota novissima. Texte des vierten bis sechzehnten Jahrhunderts, Stuttgart: Hiersemann (Quellen und Untersuchungen zur lateinischen Philologie des Mittelalters, 7).

Bischoff, Bernhard / Brown, Virgina (1985), 'Addenda to Codices Latini Antiquiores', in Medieval Studies, 57: 317-366.

Bischoff, Bernhard / Brown, Virgina / John, James J. (1992), 'Addenda to Codices Latini Antiquiores (II)', in Medieval Studies, 54: 286-307. 
Bischoff, Frank M. / Maniaci, Marilena (1996), ‘Pergamentgröße, Handschriftenformate, Lagenkonstruktion. Anmerkungen zur kodikologischen Forschung am Beispiel südeuropäischer Pergamente und Handschriften', in Scrittura e civiltà, 19: 277-319.

Bozzolo, Carla / Coq, Dominique/ Muzerelle, Denis / Ornato, Ezio (1984), 'Noir et blanc. Premiers résultats d'une enquête sur la mise en page dans le livre médiéval', in Questa, Cesare / Raffaelli, Renato (eds), Il libro e il testo. Atti del convegno internazionale (Urbino, settembre 1982), Urbino: QuattroVenti, 195-221 (repr. in [Ornato, Ezio et al.] [1997], La face cachée du livre médiéval. L'histoire du livre vue par Ezio Ornato, ses amis et ses collègues. Avec une préface d'Armando Petrucci, Roma: Viella [I libri di Viella, 10], 473-508).

Bozzolo, Carla / Ornato, Ezio (1980), Pour une histoire du livre manuscrit au Moyen Âge. Trois essais de codicologie quantitative, Paris: CNRS (Publications de l'équipe de recherche sur l'humanisme français des XIVe et $\mathrm{XV}^{\mathrm{e}}$ siècles. Textes et études, 2).

Careri, Maria et al. (eds) (2001), Album de manuscripts français du XIII' siècle. Mise en page et mise en texte, Roma: Viella.

Cavallo, Guglielmo (1984), 'Frammenti di un discorso grafico-testuale', in Questa, Cesare / Raffaelli, Renato (eds), Il libro e il testo. Atti del convegno internazionale (Urbino, 20-23 settembre 1982), Urbino: QuattroVenti, 415-429.

Cavallo, Guglielmo (1995), 'La cultura scritta a Bisanzio. Inventario di problemi per una riflessione', in Hamesse, Jacqueline (ed.), Bilan et perspectives des études médiévales en Europe. Actes du premier Congrès européen d'études médiévales (Spoleto, 27-29 mai 1993), Louvain-La-Neuve: Institut d'études médiévales (Fédération internationale des études médiévales. Textes et études du Moyen Âge, 3), 65-80.

Cherubini, Paolo (2004), 'Una nuova ricetta in volgare per rigare la pagina (secolo XV)', in Miscellanea Bibliothecae Apostolicae Vaticanae, 11, Città del Vaticano: Biblioteca Apostolica Vaticana (Studi e Testi, 423), 241-258.

Cherubini, Paolo / Pratesi, Alessandro (2010), Paleografia latina. L'avventura grafica del mondo occidentale, Città del Vaticano: Scuola Vaticana di Paleografia, Diplomatica e Archivistica (Littera antiqua, 16).

Crisci, Edoardo (2003), 'Papiro e pergamena nella produzione libraria in Oriente dal IV all'VIII secolo', in Segno e testo, 1: 79-127.

Crisci, Edoardo / Pecere, Oronzo (eds) (2004), Il codice miscellaneo, Tipologie e funzioni. Atti del convegno internazionale (Cassino, May 14-17, 2003), Cassino: Università degli studi di Cassino (= Segno e testo, 2).

Déroche, François et al. (2000), Manuel de codicologie des manuscrits en écriture arabe, Paris: Bibliothèque nationale de France (Études et recherches).

Fioravanti, Giorgio (2002), Il nuovo manuale del grafico. Guida alla progettazione grafica del prodotto editoriale: libro, rivista, giornale CD-Rom e sito web, new edition edited by F. A. Chilli, Bologna: Zanichelli.

Frank, Barbara (1993), 'Zur Entwicklung der graphischen Präsentation mittelalterlicher Texte', in Erfurt, Jürgen / Gessinger, Joachim (eds), Schriftkultur und sprachlicher Wandel, Osnabrück: Gilles \& Francke Verlag (Osnabrücker Beiträge zur Sprachtheorie, 47), 60-81.

Giovè Marchioli, Nicoletta (2010), 'Caratteri e trasformazioni della cultura scritta nel V secolo', in Delogu, Paolo / Gasparri, Stefano (eds), Le trasformazioni del V secolo. L'Italia, i Barbari e l'Occidente romano. Atti del seminario di Poggibonsi, 18-20 ottobre 2007, Turnhout: Brepols, 679-703.

Gumbert, Johan Peter (1984), IIMM. Illustrated Inventory of Medieval Manuscripts in the Netherlands, Utrecht Museum Catharijneconvent, I, Leiden: Verloren. 
Gumbert, Johan Peter (1989), 'La page intelligibile: quelques remarques', in Weijers, Olga (ed.), Vocabulaire du livre et de l'écriture au Moyen Âge. Actes de la Table ronde, Paris, 24-26 septembre 1987, Turnhout: Brepols (Civicima. Études sur le vocabulaire intellectuel du Moyen Âge, 2), 111-119.

Gumbert, Johan Peter (1992), 'Zur “Typographie” der geschriebenen Seite', in Keller, Hagen / Grubmüller, Klaus / Staubach, Nikolaus (eds), Pragmatische Schriftlichkeit im Mittelalter. Erscheinungsformen und Entwicklungsstufen. Akten des internationalen Kolloquiums 1719. Mai 1989, München: Wilhelm Fink Verlag (Münstersche Mittelalter Schriften, 65), 283292.

Gumbert, Johan Peter (2000), 'Skins, Sheets and Quires', in Pearsall, Derek (ed.), New Directions in Later Medieval Manuscript Studies. Essays from the 1998 Harvard Conference, York: Boydell \& Brewer, York Medieval Press, 81-90.

Gumbert, Johan Peter (2001), 'Livre grand, livre petit: un problème de taille', in Gazette du livre médiéval, 38: 55-58.

Irigoin, Jean (1984), 'Livre et texte dans les manuscrits byzantins de poètes; continuité et innovations', in Questa, Cesare / Raffaelli, Renato (eds), Il libro e il testo. Atti del convegno internazionale (Urbino, 20-23 settembre 1982), Urbino: QuattroVenti, 87-102.

Irigoin, Jean (1985), 'La mise en page des œuvres poétiques de l'antiquité à la fin du Xle siècle', in Lemaire, Jacques / Van Balberghe, Émile (eds), Calames et cahiers. Mélanges de codicologie et de paléographie offerts à Léon Gilissen, Bruxelles: Centre d’Étude des Manuscrits (Les publications de Scriptorium, 9), 79-87.

Irigoin, Jean (1990), 'Grégoire de Nazianze’, in Martin, Henri Jean / Vézin, Jean (eds), Mise en page et mise en texte du livre manuscrit, Paris: Editions du Cercle de La Librairie, 123-128.

John, James J. (1990), 'The Format of Manuscripts in Codices Latini Antiquiores: A Statistical Report', in Díaz y Díaz, Manuel Cecilio (ed.), Actas del VIII Coloquio del Comité Internacional de Paleografia latina, Madrid, Toledo 29 setiembre-1 octubre 1987, Madrid: Joyas Bibliográficas (Estudios y ensayos, 6), 95-105.

Johnson, William A. (2004), Bookrolls and Scribes in Oxyrhynchus, Toronto, Buffalo, London: University of Toronto Press (Studies in Book and Print Culture).

Lowe, Elias Avery (1925 [1970]), 'Some Facts about our Oldest Latin Manuscripts', in The Classical Quarterly, 19/ 3-4: 197-208 (repr. in Lowe, Elias Avery [1970], Palaeographical Papers 1907-1965, I, edited by Bieler, Ludwig, Oxford: At the Clarendon Press, 187-202).

Lowe, Elias Avery (1928 [1970]), 'More Facts about our Oldest Latin Manuscripts', in The Classical Quarterly, 22/1: 43-62 (repr. in Lowe, Elias Avery [1970], Palaeographical Papers, I, edited by Bieler, Ludwig, Oxford: At the Clarendon Press, 251-274).

Maniaci, Marilena (1995), 'Ricette di costruzione della pagina nei manoscritti greci e latini', in Scriptorium, 49: 16-41.

*Maniaci, Marilena (1999), 'L'art de ne pas couper les peaux en quatre', in Gazette du livre médiéval, 34: 1-12.

*Maniaci, Marilena (2000), 'La pergamena nel manoscritto bizantino dei secoli XI e XII: caratteristiche e modalità d'uso', in Quinio. International Journal on the History and Conservation of the Book, 2: 63-92.

Maniaci, Marilena (1999), 'Suddivisione delle pelli e allestimento dei fascicoli nel manoscritto bizantino', in Quinio. International Journal on the History and Conservation of the Book, 1: 83-122. 
*Maniaci, Marilena (2000), 'La struttura delle Bibbie atlantiche', in Maniaci, Marilena / Orofino, Giulia (eds), Le Bibbie atlantiche. Il Libro delle Scritture tra monumentalità e rappresentazione. Catalogo della mostra, Milano: Centro Tibaldi, 47-60.

Maniaci, Marilena (2002), Costruzione e gestione della pagina nel manoscritto bizantino, Cassino: Università degli studi di Cassino.

Maniaci, Marilena (2002 [2005']), Archeologia del manuscritto. Metodi, problemi, bibliografia recente, con contributi di Carlo Federici e di Ezio Ornato, Roma: Viella (I libri di Viella, 34).

Maniaci, Marilena / Ornato, Ezio (2002), 'I cataloghi di manoscritti datati: una torre di babele codicologica?', in Gazette du livre médiéval, 61: 1-11.

Martin, Henri Jean / Vézin, Jean (eds) (1990), Mise en page et mise en texte du livre manuscrit, Paris: Éditions du Cercle de la Librairie - Promodis.

Menci, Giovanna (1997), 'L'impaginazione nel rotolo e nel codice: alcune note', in Kramer, Bärbel / Luppe, Wolfgang / Maehler, Herwig / Poethke, Günther (eds), Akten des 21. Internationalen Papyrologen-Kongresses (Berlin, 13.-18.8.1995), Leipzig: Teubner, II, 682-690.

Montecchi, Giorgio (1997 [1994]), 'Le dimensioni del libro secondo la Theorica et practica di Sigismondo Fanti', in Montecchi, Giorgio (ed.), Il libro nel Rinascimento, Roma: Viella (I libri di Viella, 11), 93-107 (1 $1^{\text {st }}$ edition, Milano: La storia, 1994).

Munk Olsen, Birger (1982-1989), L'étude des auteurs classiques latins au XIe et XII siècles, IIV, Paris: CNRS.

Muzerelle, Denis (1989), 'Normes et recettes de mise en page dans le codex pré-carolingien', in Blanchard, Alain (ed.), Les débuts du codex. Actes de la journée d'études organisée à Paris les 3 et 4 juillet 1985, Turnhout: Brepols (Bibliologia, 9), 125-156.

Muzerelle, Denis (2007), 'Pour revenir sur et à la "taille” des manuscrits', in Gazette du livre médiéval, 50: 55-63.

Nelson, Robert S. / Bona, Jerry L. (1991), 'Relative Size and Comparative Value in Byzantine Illuminated Manuscripts: Some Quantitative Perspectives', in Harlfinger, Dieter / Prato, Giancarlo (eds), Paleografia e codicologia greca. Atti del Il colloquio internazionale (BerlinWolfenbüttel, 17-21 October, 1983), with the collaboration of D’Agostino, Marco / Doda, Alberto, Alessandria: Edizioni dell'Orso (Biblioteca di Scrittura e civiltà, 3), I, 339-353.

Ornato, Ezio (1997), 'L'histoire du livre et les méthodes quantitatives: bilan de vingt ans de recherche', in [Ornato, Ezio et al.], La face cachée du livre médiéval. L'histoire du livre vue par Ezio Ornato, ses amis et ses collègues. Avec une préface d'Armando Petrucci, Roma: Viella (I libri di Viella, 10), 607-679.

[Ornato, Ezio et al.] (1997), La face cachée du livre médiéval. L'histoire du livre vue par Ezio Ornato, ses amis et ses collègues. Avec une préface d'Armando Petrucci, Roma: Viella (I libri di Viella, 10)

Orsini, Pasquale (2005), Manoscritti in maiuscola biblica. Materiali per un aggiornamento, Cassino: Università di Cassino (Collana scientifica, Studi Archeologici, Artistici, Filologici, Letterari e Storici, 7).

Palma, Marco (1998), ‘Classico, piccolo e quadrato. Dati per un'indagine su una tipologia libraria nell'Europa carolingia', in Ferrari, Anna (ed.), Filologia classica e filologia romanza: esperienze ecdotiche a confronto. Atti del convegno (Roma, 25-27 maggio 1995), Spoleto: Centro italiano di studi sull'alto Medioevo (Incontri di studio, II), 399-408.

Petrucci, Armando (1972), 'Libro, scrittura e scuola', in La scuola nell'Occidente latino dell'alto medioevo (Settimana di studi sull'alto medioevo, 19) Spoleto: Centro italiano di studi sull' Alto Medioevo, 313-337 (repr. and transl. in Petrucci, Armando / Radding, Charles M. [eds], Writers and Readers in Medieval Italy. Studies in the History of Written Culture, New Haven: Yale University Press = 
Petrucci, Armando [2007], Scrivere e leggere nell'Italia medioevale, Milano: Sylvestre Bonnard, 81-97).

Sautel, Jacques-Hubert (1995), Répertoire de réglures dans les manuscrits grecs su parchemin. Base de données établie par Jacques-Hubert Sautel à l'aide du fichier Leroy et des catalogues récentes, Turnhout: Brepols (Bibliologia, 13).

Tristano, Caterina (1991), 'Caratteristiche tecnico-formali dei codici dell'Italia meridionale tra IX e X secolo', in Vitolo, Giovanni / Mottola, Francesco (eds), Scrittura e produzione documentaria nel Mezzogiorno longobardo, [Cava dei Tirreni]: Badia (Acta Cavensia, 1), 55-89.

Tristano, Caterina (2010), 'Costruire la scrittura, costruire la pagina. Dai trattati di scrittura a Luca Pacioli', in Merisalo, Outi / Tristano, Caterina (eds), Dal libro manoscritto al libro stampato. Atti del Convegno di studio (Roma, 10-12 dicembre 2009), Spoleto: Centro italiano di Studi sull'alto medioevo, 67-89.

Tschichold, Jan (1965), 'Non-arbitrary Proportion of Page and Type Area', in Osley, Arthur Sidney (ed.), Calligraphy and Palaeography. Essays presented to Alfred Fairbank on his $70^{\text {th }}$ Birthday, London: Faber \& Faber, 179-191.

Tschichold, Jan (1975), Ausgewählte Aufsätze über Fragen der Gestalt des Buches und der Typographie, Basel, Stuttgart: Birkhäuser (Italian translation Tschichold, Jan [2003], La forma del libro, Milano: Sylvestre Bonnard).

Turner, Eric Gardner (1977), The Typology of the Early Codex, Philadelphia: University of Pennsylvania Press (Hanley Foundation Series, 18). 